\title{
Productivity and Temperature as Drivers of Seasonal and Spatial Variations of Dissolved Methane in the Southern Bight of the North Sea
}

\author{
Alberto V. Borges,${ }^{1 *}$ Gaëlle Speeckaert, ${ }^{1,2}$ Willy Champenois, ${ }^{1}$ \\ Mary I. Scranton, ${ }^{3}$ and Nathalie Gypens ${ }^{2}$
}

\begin{abstract}
${ }^{1}$ Unité d'Océanographie Chimique, Institut de Physique (B5), Université de Liège, Liège 4000, Belgium; ${ }^{2}$ Laboratoire d'Ecologie des Systèmes Aquatiques, Université Libre de Bruxelles, CP221, Boulevard du Triomphe, Brussels 1050, Belgium; ${ }^{3}$ School of Marine and Atmospheric Sciences, Stony Brook University, Stony Brook, New York 11794-5000, USA
\end{abstract}

\begin{abstract}
Dissolved $\mathrm{CH}_{4}$ concentrations in the Belgian coastal zone (North Sea) ranged between $670 \mathrm{nmol} \mathrm{l}^{-1}$ nearshore and $4 \mathrm{nmol} \mathrm{l}^{-1}$ offshore. Spatial variations of $\mathrm{CH}_{4}$ were related to sediment organic matter (OM) content and gassy sediments. In nearshore stations with fine sand or muddy sediments, the $\mathrm{CH}_{4}$ seasonal cycle followed water temperature, suggesting methanogenesis control by temperature in these OM-rich sediments. In offshore stations with permeable sediments, the $\mathrm{CH}_{4}$ seasonal cycle showed a yearly peak following the chlorophyll-a spring peak, suggesting that in these OMpoor sediments, methanogenesis depended on freshly produced OM delivery. This does not exclude the possibility that some $\mathrm{CH}_{4}$ might originate from dimethylsulfide (DMS) or dimethylsulfoniopropionate (DMSP) or methylphosphonate transformations in the most offshore stations. Yet, the average seasonal $\mathrm{CH}_{4}$ cycle was unrelated to those of DMS(P), very abundant
\end{abstract}

during the Phaeocystis bloom. The annual average $\mathrm{CH}_{4}$ emission was $126 \mathrm{mmol} \mathrm{m}^{-2} \mathrm{y}^{-1}$ in the most nearshore stations ( $\sim 4 \mathrm{~km}$ from the coast) and $28 \mathrm{mmol} \mathrm{m}^{-2} \mathrm{y}^{-1}$ in the most offshore stations ( $\sim 23 \mathrm{~km}$ from the coast), 1260-280 times higher than the open ocean average value $\left(0.1 \mathrm{mmol} \mathrm{m} \mathrm{m}^{-2} \mathrm{y}^{-1}\right)$. The strong control of $\mathrm{CH}_{4}$ by sediment $\mathrm{OM}$ content and by temperature suggests that marine coastal $\mathrm{CH}_{4}$ emissions, in particular in shallow areas, should respond to future eutrophication and warming of climate. This is supported by the comparison of $\mathrm{CH}_{4}$ concentrations at five stations obtained in March 1990 and 2016, showing a decreasing trend consistent with alleviation of eutrophication in the area.

Key words: methane; North Sea; sediments; eutrophication; dimethylsulfide; dimethylsulfoniopropionate.
Received 3 May 2017; accepted 17 June 2017

Electronic supplementary material: The online version of this article (doi:10.1007/s10021-017-0171-7) contains supplementary material, which is available to authorized users.

Authors' Contributions: AVB and NG designed the experiment; GS, WC, MIS and AVB collected and measured the samples; AVB drafted the manuscript that was commented and amended by NG, MIS and WC.

*Corresponding author; e-mail: alberto.borges@ulg.ac.be

\section{INTRODUCTION}

Methane $\left(\mathrm{CH}_{4}\right)$ is the second most important greenhouse gas (GHG) after $\mathrm{CO}_{2}$ (IPCC 2013), but has a shorter residence time in the atmosphere (10 y). This means that alleviating $\mathrm{CH}_{4}$ emissions could represent an efficient option for mitigation of climate change, because $\mathrm{CH}_{4}$ accounts for $32 \%$ of the anthropogenic global radiative forcing by 
well-mixed GHGs in 2011 relative to 1750 (IPCC 2013). This requires a full account with a reasonable accuracy of the sources and sinks of $\mathrm{CH}_{4}$. Yet, there are large uncertainties in the quantification of natural and anthropogenic $\mathrm{CH}_{4}$ sources and sinks (Kirschke and others 2013; Saunois and others 2016). The open ocean is a very modest source of $\mathrm{CH}_{4}$ to the atmosphere $\left(0.4-1.8 \mathrm{TgCH}_{4} \mathrm{y}^{-1}\right.$, Bates and others 1996; Rhee and others 2009) compared to other natural $\left(220-350 \quad \mathrm{TgCH}_{4} \mathrm{Y}^{-1}\right)$ and anthropogenic (330-335 $\left.\mathrm{TgCH}_{4} \mathrm{Y}^{-1}\right) \mathrm{CH}_{4}$ emissions (Kirschke and others 2013). Coastal regions, and in particular estuarine zones, are more intense sources of $\mathrm{CH}_{4}$ to the atmosphere (Scranton and McShane 1991; Bange and others 1994; Rehder and others 1998; Upstill-Goddard and others 2000; Middelburg and others 2002; Borges and Abril 2011 ; Upstill-Goddard and Barnes 2016) than open oceanic waters. The $\mathrm{CH}_{4}$ emission to the atmosphere from coastal areas is sustained by riverine inputs and methanogenesis in the sediments due to high organic matter (OM) deposition (Scranton and McShane 1991; Middelburg and others 1996, 2002; Borges and Abril 2011). Additionally, natural gas seeps are sources of $\mathrm{CH}_{4}$ leading to high dissolved $\mathrm{CH}_{4}$ concentrations in bottom waters (from

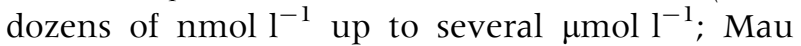
and others 2007, 2015; Solomon and others 2009; Shakhova and others 2010; Schmale and others 2010; Schneider von Deimling and others 2011; Faure and others 2010; Gentz and others 2014; Graves and others 2015). In thermally stratified conditions, $\mathrm{CH}_{4}$ removal by microbial oxidation and lateral physical transport leads to much lower $\mathrm{CH}_{4}$ concentrations in surface waters (5-20 nmol $\mathrm{l}^{-1}$ ) than in deeper waters. In contrast, in vertically well-mixed shallow coastal areas, such as the Southern Bight of the North Sea (SBNS), the $\mathrm{CH}_{4}$ is efficiently mixed from bottom waters to surface waters, leading to high $\mathrm{CH}_{4}$ concentrations and emissions to the atmosphere (Borges and others 2016).

Over-saturation of $\mathrm{CH}_{4}$ with respect to atmospheric equilibrium $(5-75 \%)$ is ubiquitous in the surface waters of the open ocean. This has been coined the "oceanic $\mathrm{CH}_{4}$ paradox" (Kiene 1991), because oceanic surface waters are well oxygenated and methanogenic archaea are assumed to be strictly anaerobic. Several hypotheses have been put forward to explain this paradox, such as the occurrence of methanogenesis in anaerobic microenvironments in organic particles and aggregates (Karl and Tilbrook 1994) or in the guts of zooplankton (Oremland 1979; De Angelis and Lee 1994). More recently, $\mathrm{CH}_{4}$ production has been linked to the transformation of methylated molecules such as methylphosphonate (Karl and others 2008; del Valle and Karl 2014; Repeta and others 2016) or dimethylsulfide (DMS), dimethylsulfoniopropionate (DMSP), dimethylsulfoxide (DMSO) and related demethylation products (methanethiol and mercaptopropionate; Damm and others 2008, 2010, 2015; Zindler and others 2013; Florez-Leiva and others 2013). Oceanic semi-labile dissolved organic matter contains methylphosphonate esters (Repeta and others 2016), whereas DMSP and DMSO are produced in large quantities by several species of phytoplankton (Keller and others 1989; Simó and Vila-Costa 2006). Yet, evidence for the formation of $\mathrm{CH}_{4}$ from $\mathrm{DMS}(\mathrm{P}, \mathrm{O})$ remains circumstantial and is mainly based on correlations between $\mathrm{CH}_{4}$ and chlorophyll-a $(\mathrm{Chl}-\mathrm{a})$ or DMS $(\mathrm{P}, \mathrm{O})$ concentrations. Further, the mechanisms of $\mathrm{CH}_{4}$ formation from $\mathrm{DMS}(\mathrm{P}, \mathrm{O})$ remain elusive, whether abiotic (Althoff and others 2014) or biologically mediated by bacteria (Damm and others 2015) or by phytoplankton (Lenhart and others 2016). Production of $\mathrm{CH}_{4}$ from methylphosphonate is attributed to microbial activity in phosphate-stressed oceanic regions (Karl and others 2008; Metcalf and others 2012; Repeta and others 2016). In freshwater lakes, $\mathrm{CH}_{4}$ concentrations correlate to phytoplankton biomass and production (Bogard and others 2014) and this has been attributed to methanogenesis in aerobic conditions by methanogen archaea fixed at the surface of phytoplankton cells (Grossart and others 2011). Whatever mechanisms are responsible for the "oceanic $\mathrm{CH}_{4}$ paradox," the $\mathrm{CH}_{4}$ production in oxic open ocean surface waters should be linked more or less directly to primary production. In shallower waters, however, high dissolved $\mathrm{CH}_{4}$ concentrations are frequently attributed to sedimentary methanogenesis in both coastal environments (for example, Oremland 1975; Crill and Martens 1983; Middelburg and others 1996; Martens and others 1998; Bange 2006; Egger and others 2016; Sawicka and Brüchert 2017) and inland waters (Bastviken and others 2004; Borges and others 2015; Stanley and others 2015) due to water depth in these environments, and close coupling between benthic and pelagic processes.

In this study, we report a yearly data set of $\mathrm{CH}_{4}$ concentrations in surface waters of the Belgian coastal zone (BCZ) obtained in 2016 at nine fixed stations, at bimonthly intervals during spring and monthly intervals during the other seasons (Figure 1). This is a shallow $(<30 \mathrm{~m})$ and permanently well-mixed coastal area with multiple possible sources of $\mathrm{CH}_{4}$ such as from rivers and gassy sedi- 


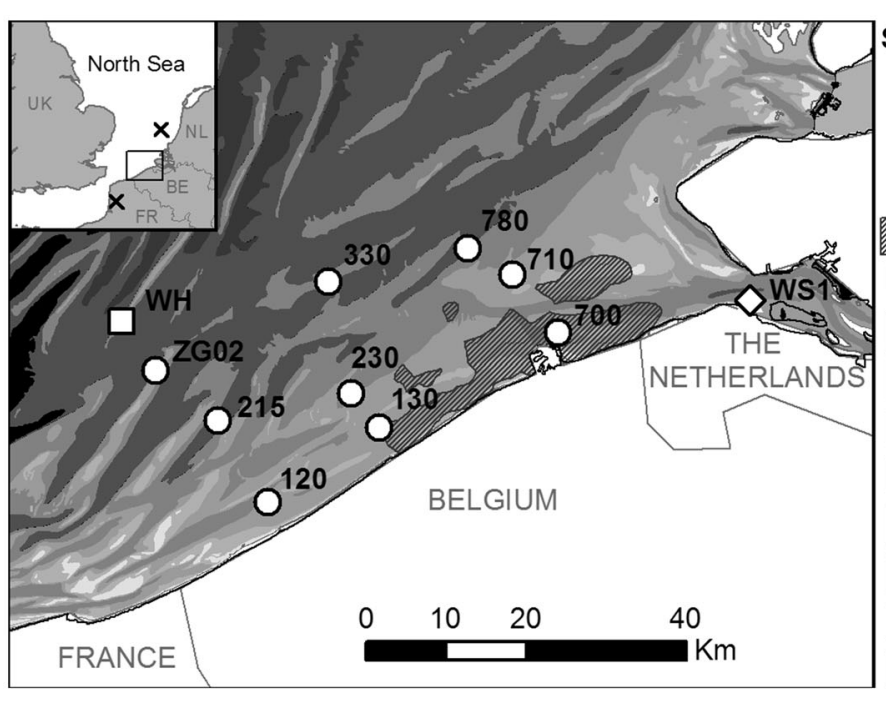

ments, and where intense phytoplankton blooms are dominated by the high DMSP producing microalgae Phaeocystis globosa (Lancelot and others 2005), leading to high DMSP and DMS concentrations (Turner and others 1988, 1996; Gypens and others 2014). Furthermore, the BCZ is a site of important $\mathrm{OM}$ sedimentation and accumulation (Mommaerts and others 1984; Verfaillie and others 2006) unlike the rest of the North Sea (de Haas and van Weering 1997).

\section{Materials And Methods}

Data were collected in 2016 during 16 cruises of 1or 2-day duration in the BCZ on the $R V$ Simon Stevin at nine fixed stations (Figure 1). Sampling was carried out in surface waters ( $3 \mathrm{~m}$ depth) with a 4-1 Niskin bottle mounted on a six-bottle rosette connected to a conductivity temperature depth (CTD) probe (Sea-bird SBE25). Sampling was only made in surface waters because we previously had shown that there are no major vertical gradients (between surface and bottom waters) of salinity, temperature and $\mathrm{CH}_{4}$ in the $\mathrm{BCZ}$ which is a permanently wellmixed area due to its shallowness and strong tidal currents (Borges and others 2016). Consequently, there is no occurrence of hypoxia in the BCZ. Duplicate water samples for the determination of dissolved $\mathrm{CH}_{4}$ concentration were collected in borosilicate serum bottles $(50 \mathrm{ml})$ with silicone tubing, left to overflow, poisoned with a saturated solution of $\mathrm{HgCl}_{2}(100 \mu \mathrm{l})$, sealed with a butyl stopper, crimped with an aluminum cap. Samples for total DMSP $\left(\right.$ DMSP $_{t} ; 10 \mathrm{ml}$ of unfiltered water) were collected in borosilicate vials $(20 \mathrm{ml})$ sealed with polytetrafluoroethylene (PTFE)-coated stoppers and stabilized with $50 \mu \mathrm{l}$ of $\mathrm{H}_{3} \mathrm{PO}_{4}(50 \%$;
Figure 1. Bathymetry of the Belgian coastal zone and the nine stations sampled in 2016 (circles), station WS1 that was sampled from 2009 to 2013 (diamond), the platform where wind speeds were measured at sea (Westhinder, WH, square) and the two National Centers for Environmental Prediction (NCEP) grid points (crosses in the inset map). Acoustic turbidity coverage is derived from Le Bot and others (2005).
Stefels 2009). We acknowledge that this method can lead to a substantial under-estimation of DMSP $_{t}$ in samples containing Phaeocystis due to cleavage by DMSP-lyase in acid conditions (del Valle and others 2011). The extent of under-estimation will be discussed in detail in a parallel study (Speeckaert and others unpublished); nevertheless, given the dominance in study zone of Phaeocystis in DMSP production compared to diatoms, and assuming a systematic bias, then the seasonal variations and spatial gradients of DMSP should be correctly captured with the present data set and sufficient for the purpose of this study (comparison of patterns of variability of DMS(P) and $\left.\mathrm{CH}_{4}\right)$. Samples for DMS (30 $\mathrm{ml}$ of unfiltered water) were collected in borosilicate vials $(50 \mathrm{ml})$ sealed with PTFE-coated stoppers. Additional samples for particulate and dissolved DMSP and DMSO were also collected but will not be presented here. Samples for the determination of Chl-a were filtered on Whatman GF/F glass fiber filters (47 $\mathrm{mm}$ diameter) and stored frozen $\left(-20^{\circ} \mathrm{C}\right)$.

The concentration of $\mathrm{CH}_{4}$ was determined with the headspace equilibration technique and a gas chromatograph (GC) equipped with a flame ionization detector (FID) (SRI 8610C) calibrated with $\mathrm{CH}_{4}: \mathrm{CO}_{2}: \mathrm{N}_{2} \mathrm{O}: \mathrm{N}_{2}$ mixtures (Air Liquide Belgium) of 1, 10 and $30 \mathrm{ppm} \mathrm{CH}_{4}$. A detailed methodological description is given by Borges and others (2016). Precision was better than $\pm 4 \%$ based on analysis of 137 duplicate samples.

The concentrations of DMS and of $\mathrm{DMSP}_{\mathrm{t}}$ (after hydrolysis into DMS with $\mathrm{NaOH}$ ) were determined by purge and trap in liquid $\mathrm{N}_{2}$ and an Agilent 7890B GC equipped with a FID and a flame photometric detector (FPD), although only the data obtained with the FPD were used. A detailed 
Table 1. Annual Average Air-Sea $\mathrm{CH}_{4}$ Flux $\left(F_{\mathrm{CH} 4}\right)$ Calculated with Wind Speeds from National Centers for Environmental Prediction (NCEP) and from the Westhinder Platform (WH) in the Belgian Coastal Zone at Nine Stations in 2016

\begin{tabular}{lcc}
\hline Station & $\begin{array}{l}\mathrm{F}_{\mathrm{CH} 4}(\mathrm{NCEP}) \\
\left(\mathrm{mmol} \mathrm{m}^{-2} \mathrm{y}^{-1}\right)\end{array}$ & $\begin{array}{c}\mathrm{F}_{\mathrm{CH} 4}(\mathrm{WH}) \\
\left(\mathrm{mmol} \mathrm{m}^{-2} \mathrm{y}^{-1}\right)\end{array}$ \\
\hline ZG02 & $3 \pm 3$ & $8 \pm 8$ \\
330 & $4 \pm 4$ & $12 \pm 13$ \\
780 & $23 \pm 25$ & $66 \pm 66$ \\
215 & $6 \pm 7$ & $17 \pm 17$ \\
230 & $8 \pm 10$ & $23 \pm 27$ \\
710 & $28 \pm 33$ & $88 \pm 116$ \\
120 & $14 \pm 14$ & $42 \pm 42$ \\
130 & $47 \pm 80$ & $152 \pm 274$ \\
700 & $61 \pm 56$ & $184 \pm 176$ \\
Nearshore stations* & $40 \pm 60$ & $126 \pm 200$ \\
Offshore stations** & $10 \pm 17$ & $28 \pm 47$ \\
All stations & $22 \pm 41$ & $66 \pm 134$ \\
& & \\
$* 120,130,700$. & & \\
$*$ ZG02, 330, 780. & & \\
\hline
\end{tabular}

methodological description is given by Borges and Champenois (2015), based on standard protocols given by Stefels (2009).

The concentration of Chl- $a$ was determined on acetone $(90 \%)$ extracts by fluorimetry (HolmHansen and others 1965) using a Kontron SFM25 fluorometer.

The air-sea $\mathrm{CH}_{4}$ flux $\left(\mathrm{F}_{\mathrm{CH}}\right)$ was computed using the gas transfer velocity parameterization as a function of wind speed of Nightingale and others (2000), and the Schmidt number of $\mathrm{CH}_{4}$ in seawater computed from temperature according to Wanninkhof (1992). We used two sets of wind speed data, a synthetic product from the National Centers for Environmental Prediction, hereafter referred to as NCEP, and at-sea measurements from a meteorological platform (Westhinder, Figure 1). Wind speed data from the NCEP reanalysis daily averages surface flux (http://www.cdc.noaa.gov/) were obtained at 2 grid points covering the sampled region $\left(3.7500^{\circ} \mathrm{E} 52.3799^{\circ} \mathrm{N} ; 0.000^{\circ} \mathrm{E} 50.4752^{\circ} \mathrm{N}\right)$ that were averaged. Daily wind speed data from the Westhinder platform $\left(2.4378^{\circ} \mathrm{E} 51.3883^{\circ} \mathrm{N}\right)$ were acquired by the Meetnet Vlaamse Banken and retrieved from the Vlaams Instituut voor de Zee (VLIZ) data center (http://www.vliz.be/en/ measurement-network-flemish-banks). We used a constant atmospheric value of $\mathrm{CH}_{4}$ of $1.9 \mathrm{ppm}$, because the dissolved $\mathrm{CH}_{4}$ concentrations were always well above atmospheric equilibrium, and the typical spatial and temporal variability of atmospheric $\mathrm{CH}_{4}$ mixing ratios of about $\pm 0.1 \mathrm{ppm}$ will have a negligible effect on the $\mathrm{F}_{\mathrm{CH} 4}$ computation.
$\mathrm{F}_{\mathrm{CH} 4}$ was computed using daily wind speed values and values of salinity, water temperature and dissolved $\mathrm{CH}_{4}$ concentrations that were interpolated linearly between cruises to obtain daily values. The daily $\mathrm{F}_{\mathrm{CH} 4}$ estimates were then averaged to obtain a yearly mean at each station (Table 1).

The georeferenced and time-stamped data set of dissolved $\mathrm{CH}_{4}$ concentration, salinity and temperature is available in a Supplemental File.

\section{Results AND Discussion \\ Spatial Variations of $\mathrm{CH}_{4}$}

The dissolved $\mathrm{CH}_{4}$ concentrations ranged across all sites and all cruises from 4 to $670 \mathrm{nmol} \mathrm{l}^{-1}$ (Figure 2). The annual average dissolved $\mathrm{CH}_{4}$ concentration showed distinct spatial gradients, with higher values nearshore, for example, $4 \mathrm{~km}$ away from the coast (stations 120, 130, 700) than offshore, for example, $23 \mathrm{~km}$ away from the coast (stations ZG02, 330,780 ). There was also a longitudinal gradient with the two most eastern stations (700 and 710) showing higher values than at other stations.

This spatial pattern might have resulted from inputs of $\mathrm{CH}_{4}$ from the nearby Scheldt estuary, as riverine-estuarine inputs have been hypothesized to be responsible for high $\mathrm{CH}_{4}$ concentrations in the SBNS and the German Bight (Scranton and McShane 1991; Rehder and others 1998; UpstillGoddard and others 2000). The surface salinity annual averages ranged between 30.5 at station 700 and 34.4 at station ZG02, testifying to the 

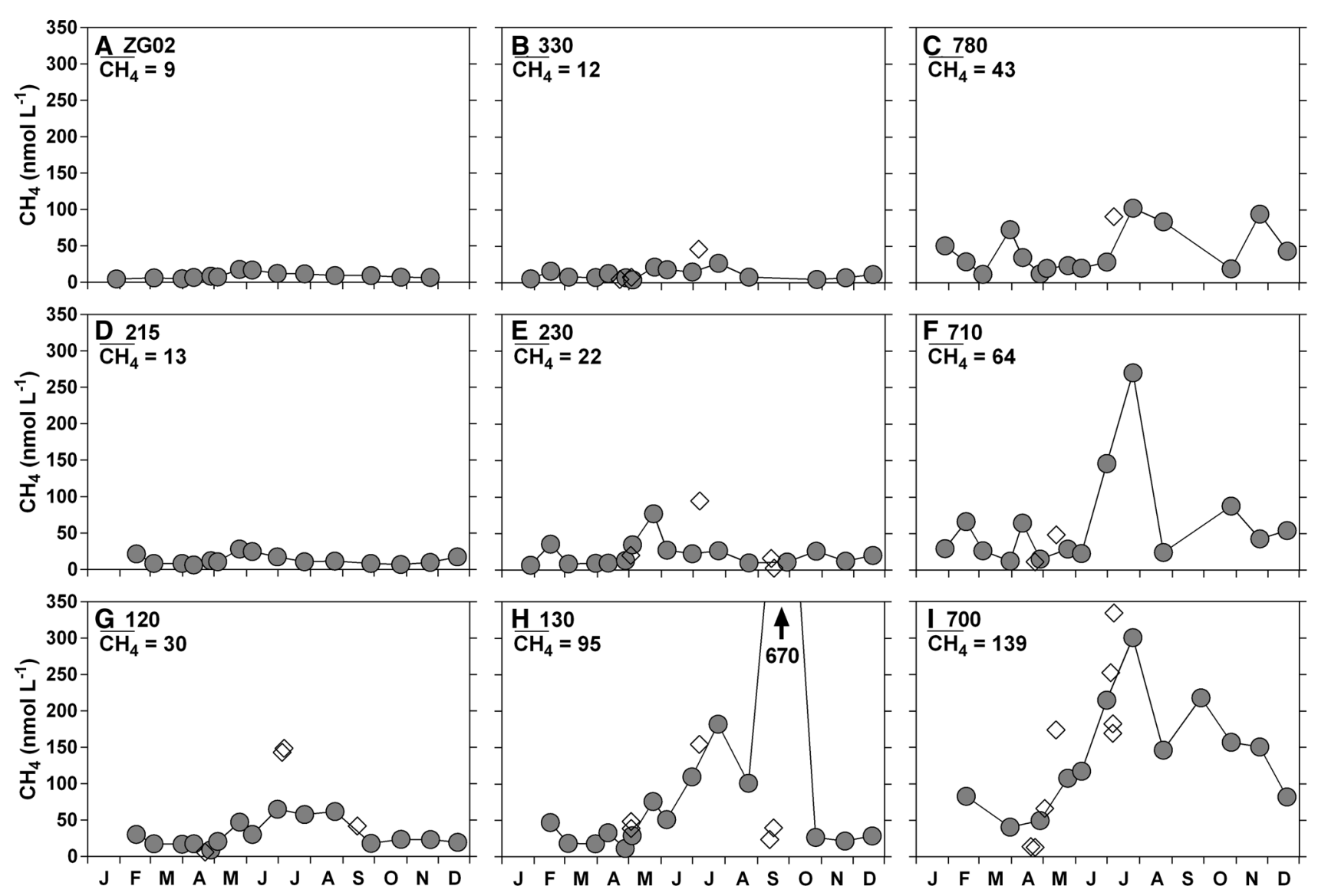

Figure 2. Seasonal variations of dissolved $\mathrm{CH}_{4}$ concentration at nine stations in the Belgian coastal zone during year 2016 (filled circles) and from the more limited data set acquired in 2010-2011 (open diamonds, Borges and others 2016). The plots are arranged to correspond to the spatial distribution of the stations (Figure 1), left to right corresponding to west to east and top to bottom corresponding from offshore to nearshore. Annual average dissolved $\mathrm{CH}_{4}$ concentration is indicated in the top left-hand corner of the plots.

influence of estuarine inputs in the BCZ (Borges and Frankignoulle 1999, 2002). We previously obtained a data set of dissolved $\mathrm{CH}_{4}$ concentrations in the Scheldt estuary from 2009 to 2013 (monthly sampling, own unpublished data). For this period, the overall average at the mouth of the Scheldt (station WS1, Figure 1) was $107 \mathrm{nmol} \mathrm{l}^{-1}$ with an average salinity of $28.5(n=70)$. This value is lower than the average value of $139 \mathrm{nmol} \mathrm{l}^{-1}$ at station 700 with an average salinity of 30.5. Stations WS1 and 700 are located about $25 \mathrm{~km}$ apart, and it requires about 5 days for the water mass to travel from the mouth of the Scheldt to station 700 (Delhez and Carabin 2001). During this travel, the $\mathrm{CH}_{4}$ will evolve as a result from the balance of sinks of $\mathrm{CH}_{4}\left[\mathrm{~F}_{\mathrm{CH}}\right.$ and microbial $\mathrm{CH}_{4}$ oxidation (MOX)] and sources of $\mathrm{CH}_{4}$ [flux from the sediments $\left(F_{\text {sed }}\right)$ ]. We modeled the evolution of a water parcel with an initial dissolved $\mathrm{CH}_{4}$ concentration of $107 \mathrm{nmol} \mathrm{l}^{-1}$ (average value at station WS1) assuming that there was no input of $\mathrm{CH}_{4}$ from the sediments $\left(F_{\text {sed }}=0\right)$, so that dissolved $\mathrm{CH}_{4}$ only changed as a function of $\mathrm{F}_{\mathrm{CH} 4}, \mathrm{MOX}$ and mixing with offshore water (average salinity increases from 28.5 to 30.0 between the stations WSI and 700). The model predicts that in 5 days the dissolved $\mathrm{CH}_{4}$ concentration decreases from 107 to $32 \mathrm{nmol} \mathrm{l}^{-1}$ (Figure 3). Although it can be argued that the parameterization of MOX we used based on the data of Ward and Kilpatrick (1990) in Saanich Inlet (British Columbia) might not be adequate for the $\mathrm{BCZ}$, the model that is only based on $\mathrm{F}_{\mathrm{CH} 4}$ also predicts a strong decrease of $\mathrm{CH}_{4}$ to $47 \mathrm{nmol} \mathrm{l}^{-1}$. Hence, it is not possible to explain the high dissolved $\mathrm{CH}_{4}$ concentrations at station 700 based only on the inputs of $\mathrm{CH}_{4}$-rich waters from the Scheldt estuary, and an additional source of $\mathrm{CH}_{4}$ is required, most likely from the sediments of the $\mathrm{BCZ}$, in line with our analysis based on mixing curves based on an earlier $\mathrm{CH}_{4}$ data set (2010- 


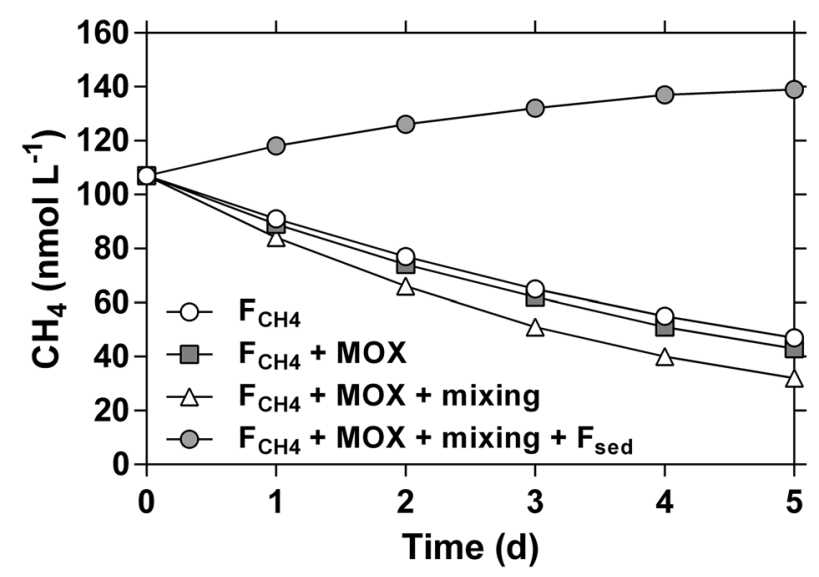

Figure 3. Modeled evolution of water parcel with an initial dissolved $\mathrm{CH}_{4}$ concentration of $107 \mathrm{nmol} \mathrm{l}^{-1}$ corresponding to the annual average at Scheldt mouth (station WS1) from a monthly monitoring from 2009 to 2013 ( $n=70$, unpublished data). The model runs during 5 days correspond to time for the water parcel to travel from the Scheldt mouth (station WS1) to station 700. The model accounts for the exchange of $\mathrm{CH}_{4}$ with atmosphere $\left(\mathrm{F}_{\mathrm{CH} 4}\right)$ computed with a constant wind speed of $5.5 \mathrm{~m} \mathrm{~s}^{-1}$, a water temperature of $12.5^{\circ} \mathrm{C}$ (both annual average values) and assuming a depth of $9 \mathrm{~m}$. The model includes methane oxidation (MOX) that was computed from a first-order parameterization derived from the data reported by Ward and Kilpatrick (1990) in Saanich Inlet (British Columbia; $\mathrm{MOX}=0.0153 *\left[\mathrm{CH}_{4}\right]$, where $\mathrm{MOX}$ is in $\mathrm{nmol} \mathrm{l}^{-1} \mathrm{day}^{-1}$ and $\left[\mathrm{CH}_{4}\right]$ is in $\mathrm{nmol} \mathrm{l}^{-1}, r^{2}=0.63$, $n=17$ ). A linear mixing between initial water parcel (salinity 28.5, average at stations WS1) and offshore water (stations ZG02, salinity 34.2, dissolved $\mathrm{CH}_{4}$ concentration of $9 \mathrm{nmol} \mathrm{l}^{-1}$ ) is used in order to attain the salinity of 30.5 at station 700 in 5 days. A simulation includes a net constant $\mathrm{CH}_{4}$ flux from the sediments $\left(F_{\text {sed }}\right)$ that was fitted to $309 \mu \mathrm{mol} \mathrm{m}{ }^{-2}$ day $^{-1}$ to force a model trajectory that attains after 5 days a final concentration $\mathrm{CH}_{4}$ of $139 \mathrm{nmol} \mathrm{l}^{-1}$ corresponding to the annual average at station 700 .

2011) with a lower seasonal coverage (Borges and others 2016). Indeed, it is possible to compute a model trajectory that predicts after 5 days a concentration of $139 \mathrm{nmol} \mathrm{l}^{-1}$ corresponding to the annual average at station 700 , if a constant $F_{\text {sed }}$ of $309 \mu \mathrm{mol} \mathrm{m}^{-2}$ day $^{-1}$ is used. The $F_{\text {sed }}$ value was fitted to force the model trajectory, and it is within the range of $F_{\text {sed }}$ values reported in estuarine and nearshore coastal environments as compiled by Borges and Abril (2011), including the rates reported by Middelburg and others (1996) from intertidal sediments of the adjacent Scheldt estuary.

If we assume that the $\mathrm{CH}_{4}$ source is not sedimentary but occurring in the water column, the corresponding volumetric source is $33 \mathrm{nmol} \mathrm{l}^{-1}$ day ${ }^{-1}$. This value is higher than the rates of $\mathrm{CH}_{4}$ production in incubations spiked with DMS(P) with samples from the Arctic Ocean $(\sim 15 \mathrm{nmol}$ $\mathrm{l}^{-1}$ day $^{-1}$, Damm and others 2010) and from the Central Chile upwelling ecosystem $(\sim 2 \mathrm{nmol}$ $l^{-1}$ day $^{-1}$, Florez-Leiva and others 2013). The incubation with Arctic Ocean water was spiked for a final concentration of DMSP of $50 \mu \mathrm{mol} \mathrm{l}^{-1}$ (Damm and others 2010), three to four orders of magnitude higher than the natural abundance of DMSP (5-60 nmol l-1 Damm and others 2010). The incubation with water from the Central Chile upwelling ecosystem was spiked for a final concentration of DMS of $6 \mathrm{nmol} \mathrm{l}^{-1}$, close to natural abundance of DMS in the area (Florez-Leiva and others 2013). In natural (non-spiked) samples, reported rates of water column $\mathrm{CH}_{4}$ production are even lower such as in aggregates of organic matter in the North Pacific Ocean $\left(\sim 0.05 \mathrm{nmol} \mathrm{l}^{-1} \mathrm{day}^{-1}\right.$, Karl and Tilbrook 1994) or from copepods during their peak of abundance during the spring bloom in Long Island Sound $\left(0.2-1.0 \mathrm{nmol} \mathrm{l}{ }^{-1}\right.$ day $^{-1}$, De Angelis and Lee 1994). Although we cannot exclude the possibility of $\mathrm{CH}_{4}$ production in the water column from methylphosphonate as described by Repeta and others (2016), it would require a daily conversion of $\sim 50 \%$ of the methylphosphonate pool. This seems unreasonably high considering that Repeta and others (2016) computed a daily cycling of $0.3 \%$ of the methylphosphonate inventory to sustain the $\mathrm{CH}_{4}$ levels in the Pacific Ocean. We estimated the possible methylphosphonate concentration in the BCZ using an average concentration of dissolved organic phosphorus (DOP) of approximately $1000 \mu \mathrm{mol} \mathrm{l} l^{-1}$ (van der Zee and Chou 2005), and assuming methylphosphonate represented approximately $7 \%$ of DOP based on the data given by Repeta and others (2016) in the Pacific Ocean. Finally, $\mathrm{CH}_{4}$ concentrations in the BCZ (range 4-670 $\mathrm{nmol} \mathrm{l}^{-1}$ ) were much higher than those typically encountered in open oceanic surface waters, less than $4 \mathrm{nmol} \mathrm{l}^{-1}$ (Rhee and others 2009), strongly suggesting additional sources of $\mathrm{CH}_{4}$ in the $\mathrm{BCZ}$ than those usually evoked to explain the " $\mathrm{CH}_{4}$ ocean paradox" such as production in aggregates, in copepod guts and from the demethylation of methylphosphonate or of $\operatorname{DMS}(\mathrm{P})$.

The most likely variable that controls the spatial patterns of benthic methanogenesis is the OM content of sediments. A positive relationship was found between the average dissolved $\mathrm{CH}_{4}$ concentration and the OM content of sediment (\%OM) reported by Braeckman and others (2014; Figure $4 \mathrm{~A})$. The $\% \mathrm{OM}$ content of shallow sediments depends on the deposition regime (for example, de 

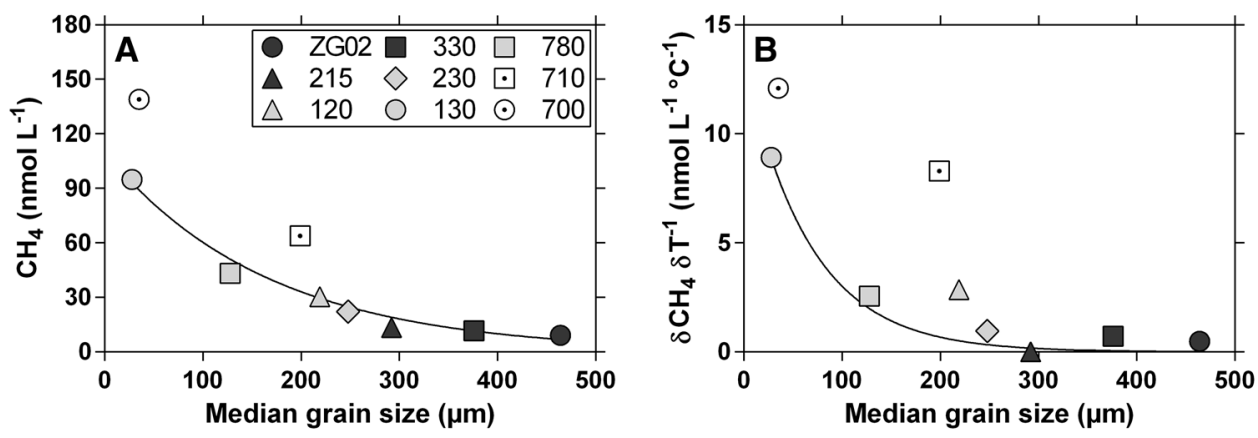

Figure 4. Annual average of dissolved $\mathrm{CH}_{4}$ concentration and change of $\mathrm{CH}_{4}$ with water temperature $\left(\delta \mathrm{CH}_{4} \delta \mathrm{T}^{-1}\right.$, computed as the slope of the linear regression of $\mathrm{CH}_{4}$ versus temperature) at nine stations in the Belgian coastal zone in 2016 as function of sediment characteristics:
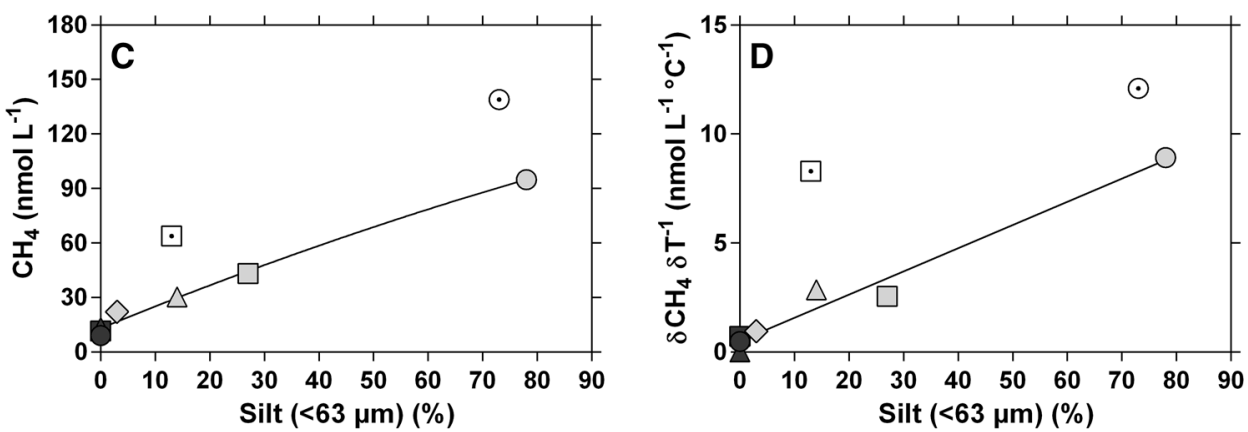
organic matter content (\%OM) (A, B), silt content [silt $(<63 \mu \mathrm{m})$ ] (C, D), median grain size $(\mathbf{E}, \mathbf{F})$ and depth $(\mathbf{G}, \mathbf{H})$. Sediment characteristics are annual averages obtained in 2011 reported by Braeckman and others (2014). Solid lines are best fit curves that provide the tendency of all stations
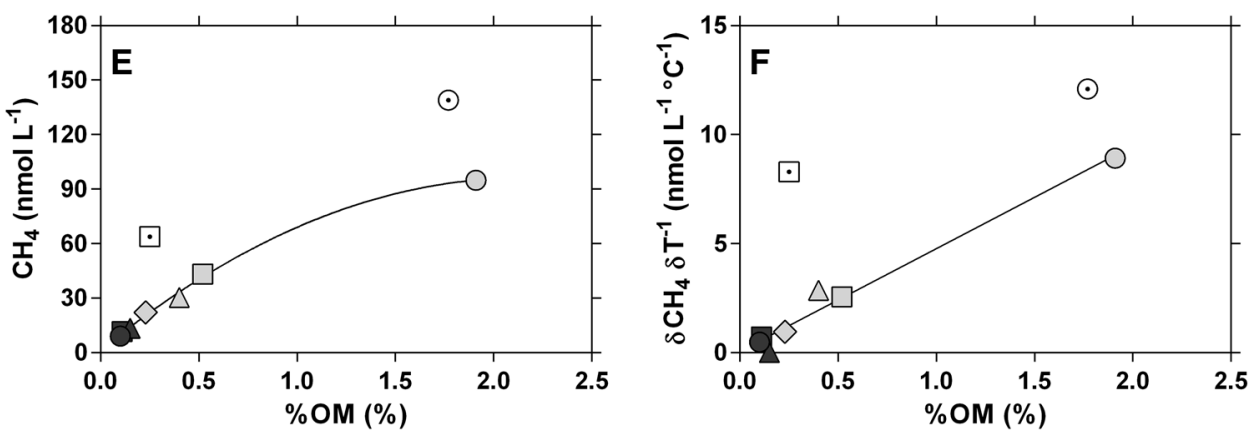
excluding 700 and 710 .
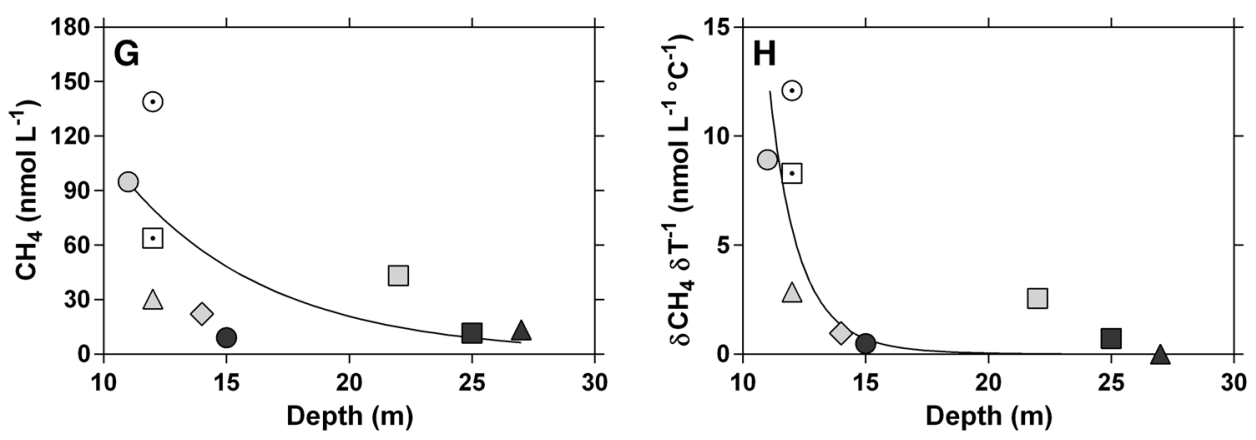

Haas and van Weering 1997); hence, a relationship was also found between average dissolved $\mathrm{CH}_{4}$ concentration and silt content (Figure 4C) and median grain size (Figure 4D). Because the high deposition sites are located in the shallower regions, a general negative relationship was also found between dissolved $\mathrm{CH}_{4}$ concentration and depth (Figure 4G). Stations 700 and 710 stand out from the overall patterns between average dissolved $\mathrm{CH}_{4}$ concentration and sediment character- istics (Figure 4A, C, E). Station 700 is located well inside of the region of acoustic turbidity (Le Bot and others 2005; Figure 1) that is indicative of gassy sediments most probably with high $\mathrm{CH}_{4}$ content (Missiaen and others 2002). This could explain the deviation of the average dissolved $\mathrm{CH}_{4}$ concentration of station 700 from the general patterns for the other stations (Figure 4A, C, E), due to additional input of $\mathrm{CH}_{4}$ from gassy sediments, that we hypothesized to be significant in the area based 

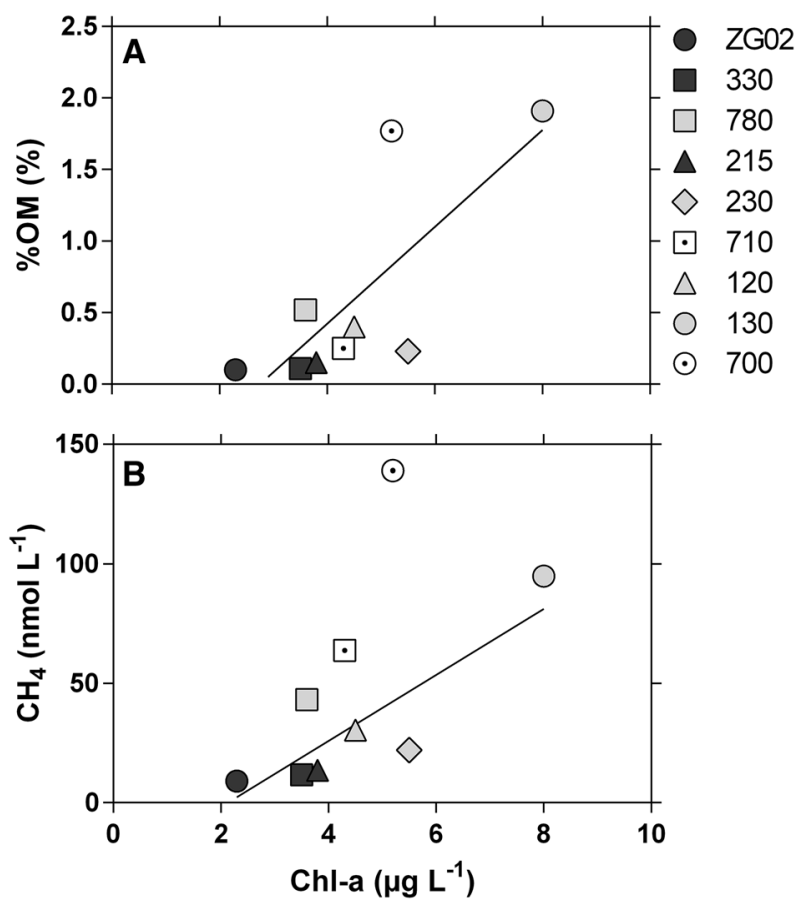

Figure 5. Relationship of annual averages of sediment organic matter content [\%OM, Braeckman and others (2014)] and water column chlorophyll-a (Chl-a) (A) and dissolved $\mathrm{CH}_{4}$ concentration and Chl- $a(\mathbf{B})$ at nine stations in the Belgian coastal zone obtained in 2016. Solid lines are best fit curves that provide the tendency of all stations excluding 700 and 710 .

on a previous data set (Borges and others 2016). The dissolved $\mathrm{CH}_{4}$ concentration of station 710, located in the near vicinity of the mapped acoustic turbidity region (Figure 1), also deviated from the general patterns with sediment characteristics, but to a lesser extent than station 700 . The general residual current direction is westward around station 700 (Delhez and Carabin 2001) so that it would be affected by the nearby surrounding gassy sediments.

There was a positive relationship between sediment \%OM and water column Chl- $a$ (Figure 5A) consistent with the hypothesis that OM deposition to surface sediments resulted in part from the above water productivity, but also on hydrodynamics that will determine the deposition regime. As a consequence, there was also an overall positive relationship between average dissolved $\mathrm{CH}_{4}$ concentration and water column Chl- $a$ (with stations 700 and 710 standing out; Figure 5B). However, this pattern is based on annual averages and does not necessarily imply a production of $\mathrm{CH}_{4}$ directly related to phytoplankton through, for example, DMS(P) transformations, as suggested in some oceanic settings such as the northwestern
Barents Sea and the western Pacific Ocean (Damm and others 2008; Zindler and others 2013) or in controlled laboratory conditions (Lenhart and others 2016).

The data of dissolved $\mathrm{CH}_{4}$ and of sediment characteristics were obtained in different years, respectively, 2016 and 2011 . The comparison of the $\mathrm{CH}_{4}$ data obtained in 2016 with the more limited data set obtained in 2010-2011 (Borges and others 2016), shows that there were inter-annual differences between data sets, more marked in the nearshore stations (for example, 700) than in the offshore ones (for example, 330; Figure 2). At stations 230 and 120, the largest differences between the 2010/11 and 2016 were observed in summer, when biological production of $\mathrm{CH}_{4}$ was more intense (see below), and possibly more variable. The larger variability in $\mathrm{CH}_{4}$ at station 700 is consistent with inputs from gassy sediments at this particular station since gas flaring is irregular in time (for example, Schneider von Deimling and others $2011)$. We tried to quantify inter-annual variations of sediment characteristics using a data set of median grain size and silt content $(<63 \mu \mathrm{m})$ obtained at five stations $(120,230,330,700,780)$ once or twice a year from 2007 to 2013 (Bavo De Witte, Flemish Institute for Agricultural and Fish-
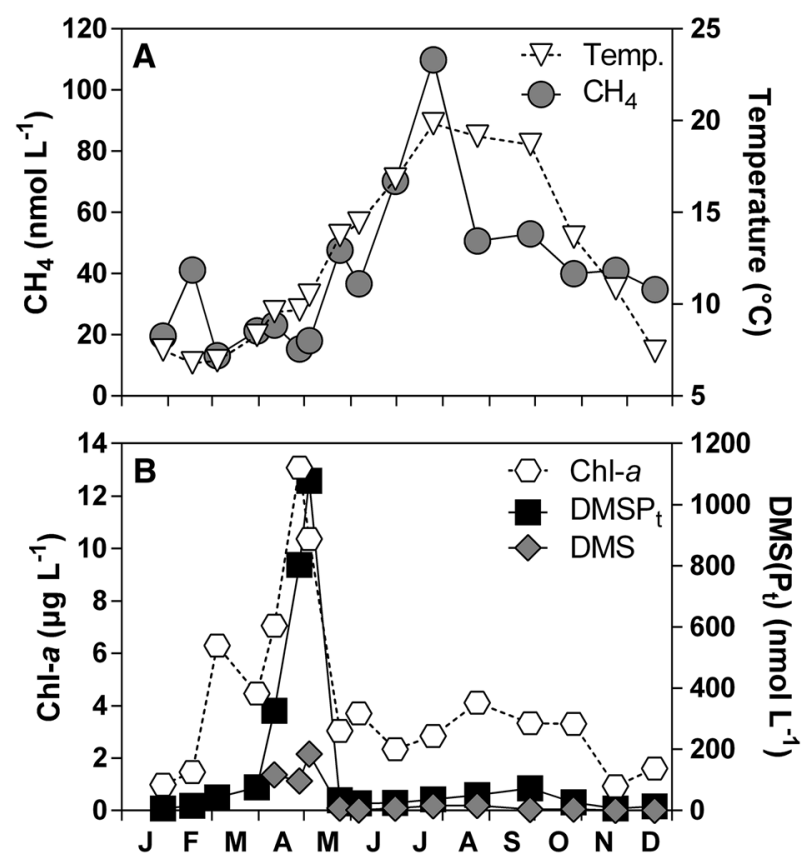

Figure 6. Seasonal variation of average values of the nine stations per cruise of dissolved $\mathrm{CH}_{4}$ concentration, water temperature, chlorophyll-a (Chl-a) concentration, total dimethylsulfoniopropionate $\left(\mathrm{DMSP}_{\mathrm{t}}\right)$ and dimethylsulfide (DMS) in the Belgian coastal zone during year 2016. 

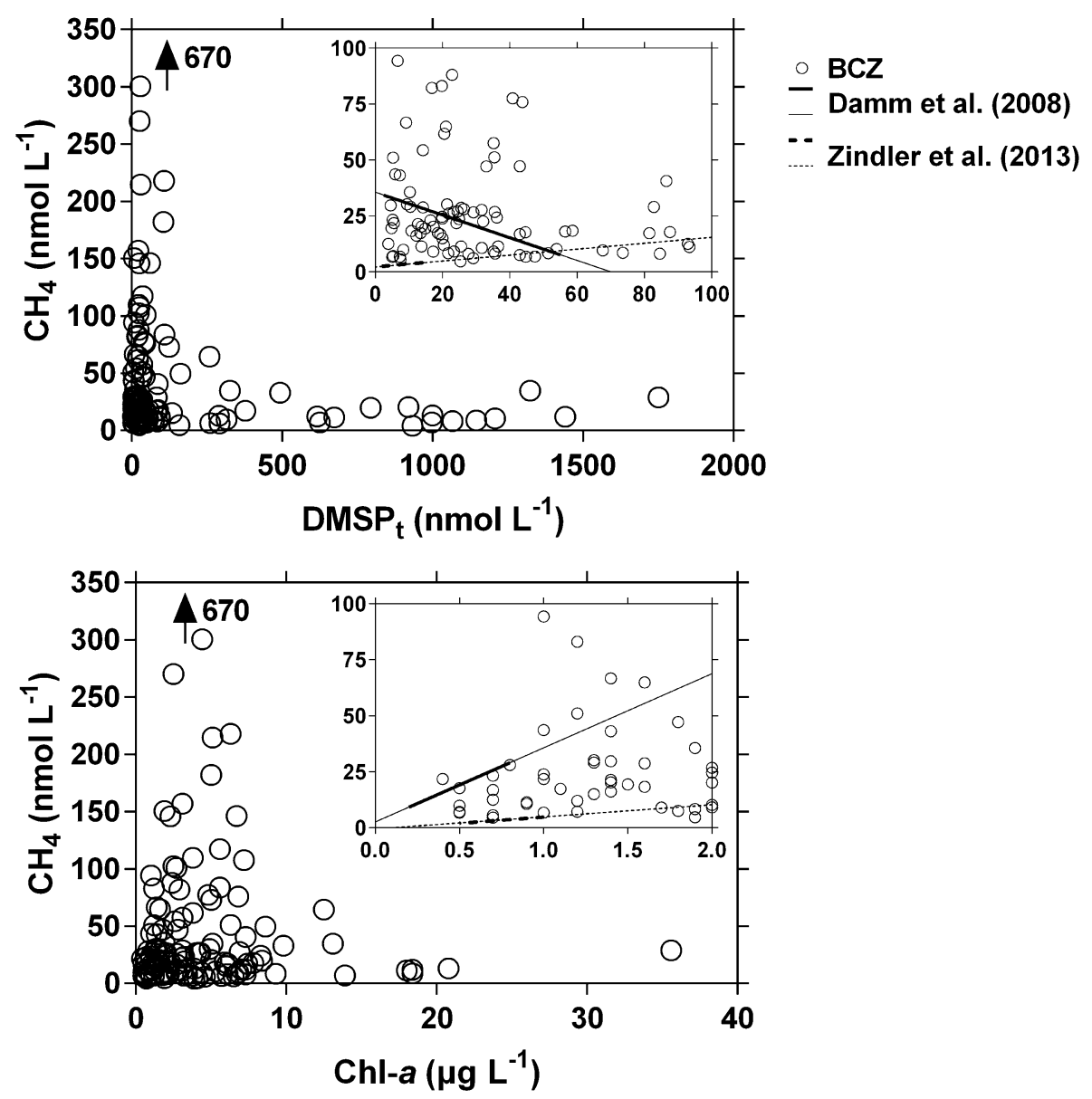

Figure 7. Dissolved $\mathrm{CH}_{4}$ concentration versus total dimethylsulfoniopropionate (DMSP $\mathrm{t}_{\mathrm{t}}$ and chlorophyll- $a$ (Chl- $a$ ) in the Belgian coastal zone at nine stations during year 2016. Inset shows the relationships between $\mathrm{CH}_{4}$ and $\mathrm{DMSP}_{\mathrm{t}}$ and $\mathrm{Chl}_{-} a$ established in Storfjorden [solid line, Damm and others (2008)] and in the western Pacific Ocean [dotted line, Zindler and others (2013)]. The thicker lines indicate the range constrained by data to calculate the regression lines.

eries Research, personal communication). At individual stations, the median grain size showed a variance ranging between 3\% (station 230) and $48 \%$ (station 700), yet, despite year-to-year variability, the differences among stations were highly significant for both median grain size and silt content (one-way Kruskal-Wallis analysis of variance test, $p<0.0001)$. We recognize that the dissolved $\mathrm{CH}_{4}$ and sedimentary data sets show year-to-year variability, but the spatial gradients (differences among stations) are overwhelming higher than year-to-year variability; consequently, the conclusions based on the analysis of the spatial gradients should be robust.

\section{Seasonal Variations of $\mathrm{CH}_{4}$}

The seasonal amplitude of dissolved $\mathrm{CH}_{4}$ concentration at each station (computed as the difference of yearly maximum and minimum) was very variable from one station to another (Figure 2) ranging from 13 to $658 \mathrm{nmol}^{-1}$, at stations ZG02 and 130, respectively. The overall seasonal cycle of $\mathrm{CH}_{4}$ in the BCZ (average of all stations) indicated a yearly minimum in late winter and a maximum in mid-summer following the seasonal temperature cycle (Figure 6A). The seasonal variation of average Chl- $a$ followed the typical cycle previously described in the area (Borges and Frankignoulle 1999, 2002; Rousseau and others 2002; Lancelot and others 2005) with a first peak in March $\left(6.3 \pm 1.7 \mu \mathrm{g}^{-1}\right)$ corresponding to the spring diatom bloom and a more intense peak in late April $\left(13.1 \pm 6.0 \mu \mathrm{g} \mathrm{l}^{-1}\right)$ corresponding to the Phaeocystis bloom (Figure 6B). The concentrations of $\mathrm{DMSP}_{\mathrm{t}}$ and DMS peaked during the Phaeocystis bloom, with maximal average values of $1079 \pm 379$ and $184 \pm 71 \mathrm{nmol} \mathrm{l}^{-1}$, respectively. These values 

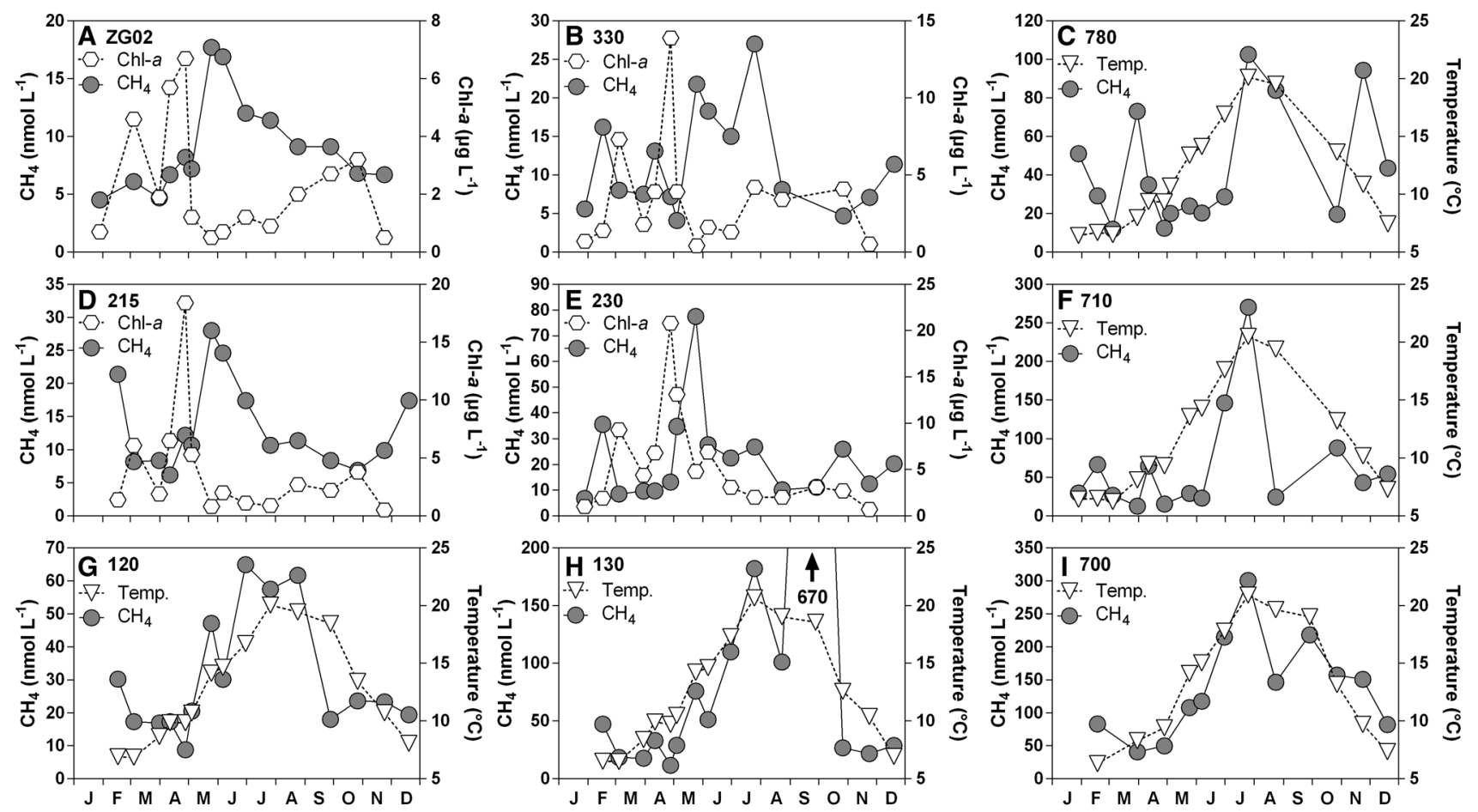

Figure 8. Seasonal variations of dissolved $\mathrm{CH}_{4}$ concentration, chlorophyll-a (Chl-a) concentration and water temperature $\left({ }^{\circ} \mathrm{C}\right)$ at nine stations in the Belgian coastal zone during year 2016. The plots are arranged to correspond to the spatial distribution of the stations (Figure 1), left to right corresponding to west to east and top to bottom corresponding from offshore to nearshore.

were higher than those previously reported in the SBNS (Turner and others 1988, 1996) that were compiled and summarized by Gypens and others (2014). This difference is probably related to the fact that previous data were obtained in more offshore and less productive waters, and this will be further investigated and discussed in detail in a parallel study (Speeckaert and others unpublished).

The average dissolved $\mathrm{CH}_{4}$ concentration peaked in late July (Figure 6A), 82 days after the peak of DMSP $_{t}$ and DMS (Figure 6B). This would suggest that the $\mathrm{CH}_{4}$ production in the $\mathrm{BCZ}$ is unrelated to DMS $(\mathrm{P})$ transformations in the water column, contrary to the findings in other oceanic areas (Damm and others 2008, 2010, 2015; Zindler and others 2013; Florez-Leiva and others 2013). The latter are in part based on correlations between $\mathrm{CH}_{4}$ and Chl- $a$ or $\mathrm{CH}_{4}$ and DMSP. In the $\mathrm{BCZ}, \mathrm{CH}_{4}$ was uncorrelated to DMSP $_{\mathrm{t}}$ and Chl-a (Figure 7), and $\mathrm{CH}_{4}$ concentrations were markedly above the regression lines of $\mathrm{CH}_{4}$ versus $\mathrm{DMSP}_{\mathrm{t}}$ and versus Chl- $a$ established in western Pacific Ocean by Zindler and others (2013). This would suggest additional sources of $\mathrm{CH}_{4}$ in the $\mathrm{BCZ}$ (such as sedimentary sources) than those usually evoked to explain the " $\mathrm{CH}_{4}$ ocean paradox." Damm and others (2008) also reported a correlation between $\mathrm{CH}_{4}$ and Chl- $a$ and DMSP (albeit negative) in Storfjorden, although the surface $\mathrm{CH}_{4}$ concentrations up to $40 \mathrm{nmol} \mathrm{l}^{-1}$ were higher than those typically encountered in open oceanic surface waters $\left(<4 \mathrm{nmol} \mathrm{l}^{-1}\right.$; Rhee and others 2009), possibly owing to the shallowness and coastal character of Storfjorden $(\sim 120 \mathrm{~m}$ depth$)$. Although our findings do not invalidate the hypothesis of $\mathrm{CH}_{4}$ formation from DMS(P) in open oceanic regions, we show that in some coastal waters where DMS $(\mathrm{P})$ production is extremely intense (Figure $6 \mathrm{~B}$ ), $\mathrm{CH}_{4}$ is mainly related to sedimentary sources that are assumed to be related to benthic methanogenesis and leakage from gassy sediments (Figure 4). This does not exclude the possibility that some of the $\mathrm{CH}_{4}$ might originate from $\mathrm{DMS}(\mathrm{P})$ transformation in the sediments, although the turnover of these compounds is usually quite fast in the water column from a few hours to approximately 1 day (Stefels and others 2007). Copepod biomass has been reported to peak during the early spring diatom bloom in the BCZ, as these organisms are unable to ingest colonies of Phaeocystis (Gasparini and others $2000)$, so that it is also unlikely that the dissolved $\mathrm{CH}_{4}$ concentration maximum in summer is related 

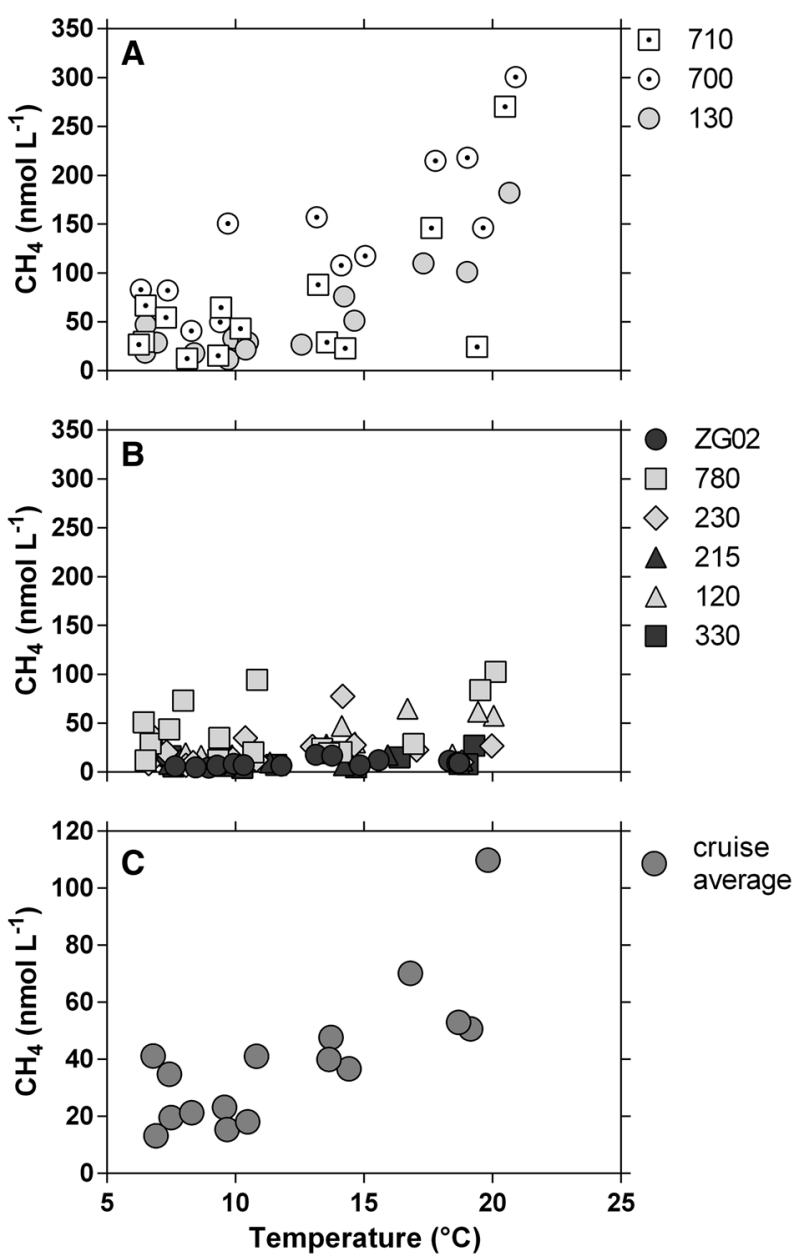

Figure 9. Relationship between dissolved $\mathrm{CH}_{4}$ concentration and water temperature in the Belgian coastal zone at nine stations during year 2016, for nearshore muddy stations (A), for the other stations (B) and for the cruise averages $(\mathbf{C})$.

to $\mathrm{CH}_{4}$ production in copepod guts (De Angelis and Lee 1994).

A closer scrutiny of the seasonal cycles of $\mathrm{CH}_{4}$ at each station allowed us to distinguish two different behaviors regarding $\mathrm{CH}_{4}$ dynamics and their relation to sediment processes. In the nearshore stations with the highest sediment $\mathrm{OM}$ content $(\% \mathrm{OM}>0.4 \% ; 120,130,700,710$ and 780$)$ that were classified as muddy or fine sandy (Braeckman and others 2014), the seasonal cycle of dissolved $\mathrm{CH}_{4}$ concentration closely followed the seasonal cycle of water temperature (Figure 8), suggesting the control of methanogenesis by temperature in these OM replete sediments. This is consistent with a temperature control of the seasonal variation of benthic remineralization (sediment oxygen demand) in a muddy station of the BCZ (Provoost and others 2013) and the seasonal variations of sedi-

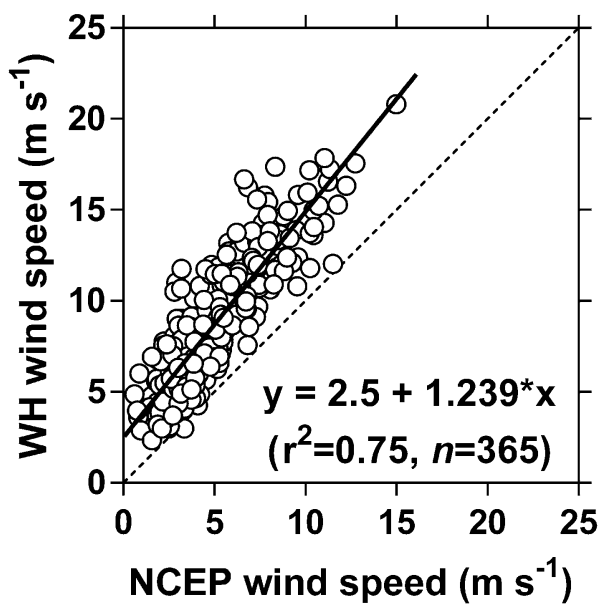

Figure 10. Comparison of daily wind speeds for 2016 measured at sea in a platform (Westhinder, WH) and from a synthetic product (National Centers for Environmental Prediction, NCEP). Dotted line indicates the $1: 1$ line, the solid line indicates the linear regression.

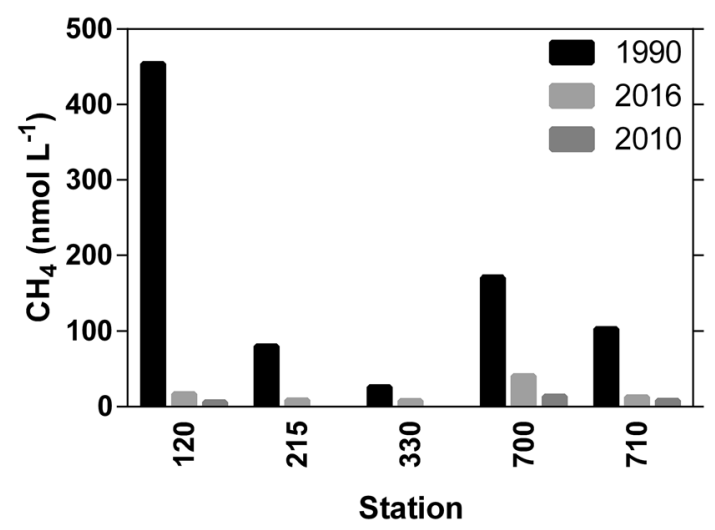

Figure 11. Comparison of dissolved $\mathrm{CH}_{4}$ concentrations at five stations in the Belgian coastal zone obtained in March 12-14, 1990, and March 30-31, 2016, and at three stations in April 22-23, 2010 (Borges and others 2016). Data in March 1990 were measured by gas chromatography according to the protocols given by Scranton and McShane (1991).

ment-air $\mathrm{CH}_{4}$ fluxes from inter-tidal muddy sediments in the adjacent Scheldt estuary (Middelburg and others 1996). The highest $\mathrm{CH}_{4}$ concentration of $670 \mathrm{nmol} \mathrm{l}^{-1}$ was measured at station 130 in September 2016 that was higher than the value of September 2010 (Figure 2). Although the exact explanation for such a high value is not known, it occurred after a long spell of warm weather of nearly two months with water temperatures above $18^{\circ} \mathrm{C}$. In the offshore stations with lowest sediment OM content $(\% \mathrm{OM}<0.3 ; 215,230,330, \mathrm{ZG02})$ that were classified as permeable (Braeckman and 


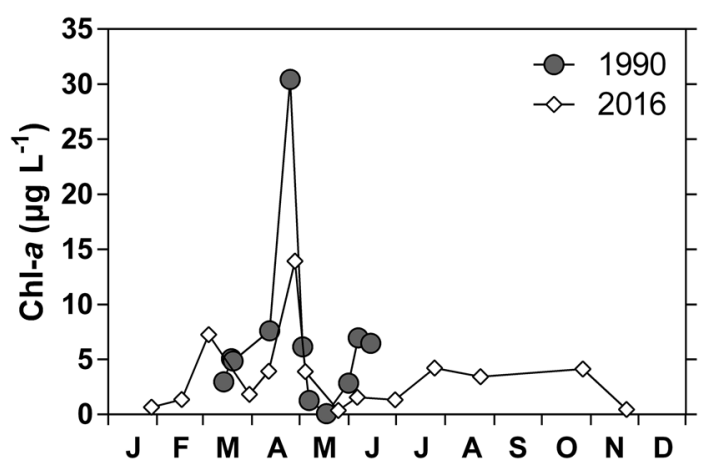

Figure 12. Comparison of chlorophyll-a (Chl-a) concentration at station 330 of the Belgian coastal zone in 1990 and 2016. Data were measured with the same method and protocol by the same laboratory (Laboratoire d'Ecologie des Systèmes Aquatiques). Historical data that are methodologically consistent for comparison are only available for station 330 that is located offshore, although stations closer to shore are typically more productive (for example, Borges and Frankignoulle 2002), so that the contrast between the two periods could have been even more marked at these nearshore stations.

others 2014), the seasonal cycle of dissolved $\mathrm{CH}_{4}$ concentration was different and was marked by a yearly peak following the Chl-a spring peak. This suggests that, in these OM-poor sediments, methanogenesis depended on the delivery to the sediments of freshly produced organic matter, as also observed in Eckernförde Bay (Baltic Sea) by Bange and others (2010). The increase of $\mathrm{CH}_{4}$ followed within a month of the decrease of Chl- $a$ due to the shallowness of the area $(<30 \mathrm{~m}$, Figure 1$)$, leading to a transfer of OM from the surface waters to the surface of sediment that was nearly immediate. This is consistent with the seasonal variation of benthic remineralization (sediment oxygen demand) in permeable sediments of the adjacent English Channel that also peaked seasonally in response to deposition of fresh organic matter following the Phaeocystis bloom (Rauch and others 2008).

A positive relation between dissolved $\mathrm{CH}_{4}$ concentration and water temperature was observed on an individual station basis for the nearshore muddy stations (Figure 9A) and also for the cruise averages (Figure 9C), but in the offshore more permeable sediments the $\mathrm{CH}_{4}$ concentration was unrelated to temperature (Figure 9B). These patterns suggest the importance of temperature control of methanogenesis in the stations that have OM-rich sediments. The optimum temperature for methanogenic archaea is around $35-40^{\circ} \mathrm{C}$, so that below those temperatures and in an environment rich in
OM, we would expect a positive relationship between methanogenesis and temperature (Zeikus and Winfrey 1976; Schulz and others 1997; YvonDurocher and others 2014).

This can also explain our observation that the change of $\mathrm{CH}_{4}$ as a function of temperature $\left(\delta \mathrm{CH}_{4}\right.$ $\delta \mathrm{T}^{-1}$ ) showed the same patterns as the dissolved $\mathrm{CH}_{4}$ concentration [positively related to \%OM and silt content (Figure 4B, D), negatively related to median grain size and depth (Figure $4 \mathrm{~F}, \mathrm{H}$ )]. It should be noted that higher temperature increases methanogenesis but can also enhance the flux of $\mathrm{CH}_{4}$ from gassy sediments that we hypothesize to be important at stations 700 and 710. Indeed, the decrease of solubility of $\mathrm{CH}_{4}$ in response to warming leads to enhanced ebullition from sediments (Martens and others 1998; Wever and others 1998). Below $10^{\circ} \mathrm{C}$, the dissolved $\mathrm{CH}_{4}$ concentration was relatively low (Figure 9A, B, C), uniform and unrelated to temperature, suggesting that $\mathrm{CH}_{4}$ inputs from sediments were low and/or compensated by loss terms such as physical dispersion, $\mathrm{CH}_{4}$ emission to the atmosphere and MOX, although MOX is also a temperature-dependent process (Yvon-Durocher and others 2014).

\section{Air-Sea $\mathrm{CH}_{4}$ Fluxes}

We used two sets of wind speed data to compute $\mathrm{F}_{\mathrm{CH} 4}$, one based on in situ measurements (Westhinder platform) and another modeled (NCEP), for a consistent comparison with previous estimates of $\mathrm{F}_{\mathrm{CH} 4}$ in the $\mathrm{BCZ}$ that were computed using NCEP winds (Borges and others 2016). The wind speeds from the NCEP product have been previously shown to be under-estimated (Smith and others 2001); the comparison of the two wind speed data shows that the NCEP data have an offset of $2.5 \mathrm{~m} \mathrm{~s}^{-1}$ compared to in situ data (Westhinder; Figure 10). This has a considerable effect on the $\mathrm{F}_{\mathrm{CH} 4}$ computations that were about 2.7 times higher when computed from the in situ data (Westhinder) than with the NCEP data (Table 1). The $\mathrm{F}_{\mathrm{CH} 4}$ values computed with the NCEP wind speed were consistent with the $\mathrm{F}_{\mathrm{CH} 4}$ values in the same area computed with the same wind product from a more limited $\mathrm{CH}_{4}$ data set obtained in 2010 2011 (Borges and others 2016). Hereafter, only the $\mathrm{F}_{\mathrm{CH} 4}$ data computed with the in situ wind speed data (Westhinder) are discussed. The annual $\mathrm{F}_{\mathrm{CH} 4}$ values ranged from 8 to $184 \mathrm{mmol} \mathrm{m}^{-2} \mathrm{y}^{-1}$ at stations ZG02 and 700, respectively (Table 1). Annual average $\mathrm{F}_{\mathrm{CH} 4}$ was $126 \mathrm{mmol} \mathrm{m}^{-2} \mathrm{y}^{-1}$ in the nearshore area, that is approximately $4 \mathrm{~km}$ of the coastline (stations 120, 130 and 700), and 
$28 \mathrm{mmol} \mathrm{m}{ }^{-2} \mathrm{y}^{-1}$ in the offshore area, that is approximately $23 \mathrm{~km}$ of the coastline (stations ZG02, 330 and 780). These values are high compared to the range of global average $\mathrm{F}_{\mathrm{CH} 4}$ from 8 to $14 \mathrm{mmol} \mathrm{m}{ }^{-2} \mathrm{y}^{-1}$ in continental shelves (mostly in seasonally stratified regions; Bange and others 1994) and the global average of open oceanic waters $\left(0.07-0.18 \mathrm{mmol} \mathrm{m}^{-2} \mathrm{y}^{-1}\right.$; Bates and others 1996; Rhee and others 2009).

\section{Comparison with Data from 1990}

Dissolved $\mathrm{CH}_{4}$ concentrations were measured at five stations in the BCZ in March 1990 (Scranton and McShane 1991) that can be compared to data acquired at the same stations in March 2016 (Figure 11). The average water temperature in March $1990\left(8.7 \pm 0.5^{\circ} \mathrm{C}\right)$ was similar to the one in March $2016\left(8.3 \pm 0.2^{\circ} \mathrm{C}\right)$, as well as average salinity $(33.5 \pm 1.4$ in 1990 vs. $32.8 \pm 2.0$ in 2016) and average monthly wind speed $\left(6.2 \pm 2.4 \mathrm{~m} \mathrm{~s}^{-1}\right.$ in 1990 vs. $5.5 \pm 2.1 \mathrm{~m} \mathrm{~s}^{-1}$ in 2016). This suggests that the two cruises were comparable with regard to the seasonal biological and physical cycles. The $\mathrm{CH}_{4}$ concentrations in March 1990 ranged between 26 and $454 \mathrm{nmol} \mathrm{l}^{-1}$ and were systematically higher than in March 2016 when they ranged between 8 and $41 \mathrm{nmol}^{-1}$. The same spatial gradients as present day (Figure 2) were observed in March 1990 with higher concentrations in nearshore stations $(120,700$ and 710$)$ than offshore stations $(215,330)$. The largest difference between March 1990 and 2016 was observed at a nearshore station (26.8 times higher at station 120 in 1990 than 2016) and the lowest difference at a more offshore station (3.5 times higher at station 330 in 1990 than 2016). The differences of $\mathrm{CH}_{4}$ concentration between 1990 and 2016 can be due to longterm trends or inter-annual variability. We do not have additional data in March of other years to evaluate inter-annual variability, but data from April 2010 (Borges and others 2016) at three stations $(120,700$ and 710$)$ are also much lower than the March 1990 values (Figure 11).

Older $\mathrm{CH}_{4}$ data for comparison with present-day data are very rare in marine environments; hence, this comparison $26 \mathrm{y}$ apart can only be made in the BCZ for a single month. The conclusions from such a comparison then need to be interpreted cautiously; nevertheless, the tendency of a decrease of $\mathrm{CH}_{4}$ concentrations in the BCZ between 1990 and 2016 is consistent with a strong decrease in primary production in the area since the mid-1980s (Lancelot and others 2007). This is consistent with the data of Chl-a measured by the same laboratory and with the same protocols and instrumentation available in 1990 and 2016 for station 330, showing maximal yearly values higher in 1990 than 2016 (Figure 12). The decrease since the mid-1980s of primary production resulted from river nutrient load reduction policies and has been shown to also strongly affect the $\mathrm{CO}_{2}$ and DMS concentrations and air-sea fluxes in the BCZ (Gypens and others 2009; Gypens and Borges 2014). A decrease of primary production would result in a decrease of OM delivery to the sediments that drives the benthic $\mathrm{CH}_{4}$ production (Figure 4). Although the water temperature during the two cruises in 1990 and 2016 were comparable, the long-term trend in the North Sea for that period is a fast increase in temperature at a rate of $0.035^{\circ} \mathrm{C} \mathrm{y}^{-1}$ (Høyer and Karagali 2017). This would imply that despite the warming of nearly $1{ }^{\circ} \mathrm{C}$ from 1990 to 2016, the change primary production had a much more important effect on $\mathrm{CH}_{4}$ concentrations in the BCZ.

The BCZ has experienced during the last decades a decrease in eutrophication that probably resulted in a decrease of $\mathrm{CH}_{4}$ production in sediments and $\mathrm{CH}_{4}$ concentrations in surface waters (Figure 11). The corollary implies an increase of $\mathrm{CH}_{4}$ production and emission might be expected from eutrophication that is ongoing in numerous coastal marine areas worldwide (for example, Díaz and Rosenberg 2008). The positive relationships between dissolved $\mathrm{CH}_{4}$ concentration and water temperature and sediment OM content we found in the study area suggest that an increase of emissions of $\mathrm{CH}_{4}$ from coastal areas may occur in response to warming of surface waters and an increase in OM deposition due to eutrophication. Warming of superficial sediments should be more acute in permanently well-mixed continental shelves, which account for about one-third of total continental shelf areas. In addition, in permanently well-mixed continental shelves the transfer of $\mathrm{CH}_{4}$ from bottom waters to surface waters (hence emission to atmosphere) is much more efficient than in seasonally thermally stratified continental shelves (Borges and others 2016). This scenario contrasts with the one of Naqvi and others (2010) who postulated that in open oceanic regions the $\mathrm{CH}_{4}$ emissions should not change in response to climate warming and expanding oxygen minimum zones, because an enhancement of methanogenesis was assumed by these authors to be compensated by an increase of MOX.

\section{ACKNOWLEDGEMENTS}

We are grateful to the crew of the RV Simon Stevin for assistance during the cruises, to André Cattrijsse 
and Jonas Mortelmans (VLIZ) for organizing the schedule of cruises, to the Royal Netherlands Institute of Sea Research (Yerseke) and the crew of the $R V$ Luctor for sampling at station WS 1, to Bavo De Witte (Instituut voor Landbouw-en Visserijonderzoek-ILVO) for providing a data set of sediment characteristics that allowed a preliminary data analysis, to Thibault Lambert for producing Figure 1, to Marc-Vincent Commarieu, Colin Royer and Adriana Anzil for help with sampling and laboratory analysis, Ruth Lagring (Belgian Marine Data Centre) for help in data mining and two anonymous reviewers for stimulating comments on the previous version of the manuscript. CTD data were provided by VLIZ and acquired in the frame of LifeWatch. This is a contribution to Belgian Science Policy (BELSPO) project 4DEMON (4 decades of Belgian marine monitoring, uplifting historical data to today's needs, BR/121/A3/4DEMON). The GCs were acquired with funds from the Fonds National de la Recherche Scientifique (FNRS) (2.4.598.07, 2.4.637.10). NG received financial support from the Fonds David et Alice Van Buuren. GS has a Ph.D. Grant from the FRIA (Fund for Research Training in Industry and Agriculture, FNRS). AVB is a senior research associate at the FNRS.

\section{REFERENCES}

Althoff F, Benzing K, Comba P, McRoberts C, Boyd DR, Greiner S, Keppler F. 2014. Abiotic methanogenesis from organosulfur compounds under ambient conditions. Nat Commun 5:4205. doi:10.1038/ncomms5205.

Bange HW. 2006. Nitrous oxide and methane in European coastal waters. Estuar Coast Shelf Sci 70:361-74.

Bange HW, Bartell UH, Rapsomanikis S, Andreae MO. 1994. Methane in the Baltic and North seas and a reassessment of the marine emissions of methane. Global Biogeochem Cycles 8:465-80.

Bange HW, Bergmann K, Hansen HP, Kock A, Koppe R, Malien F, Ostrau C. 2010. Dissolved methane during hypoxic events at the Boknis Eck time series station (Eckernförde Bay, SW Baltic Sea). Biogeosciences 7:1279-84.

Bastviken D, Cole J, Pace M, Tranvik L. 2004. Methane emissions from lakes: dependence of lake characteristics, two regional assessments, and a global estimate. Global Biogeochemical Cycles 18:GB4009. doi:10.1029/2004GB0 02238.

Bates TS, Kelly KC, Johnson JE, Gammon RH. 1996. A reevaluation of the open ocean source of methane to the atmosphere. J Geophys Res 101(D3):6953-61.

Bogard MJ, del Giorgio PA, Boutet L, Garcia Chaves MC, Merante A, Prairie YT, Derry AM. 2014. Oxic water column methanogenesis as a major component of aquatic $\mathrm{CH}_{4}$ fluxes. Nat Commun 5:5350. doi:10.1038/ncomms6350.

Borges AV, Frankignoulle M. 1999. Daily and seasonal variations of the partial pressure of $\mathrm{CO}_{2}$ in surface seawater along Belgian and southern Dutch coastal areas. J Mar Syst 19:251-66.
Borges AV, Frankignoulle M. 2002. Distribution and air-water exchange of carbon dioxide in the Scheldt plume off the Belgian coast. Biogeochemistry 59:41-67.

Borges AV, Abril G. 2011. Carbon dioxide and methane dynamics in estuaries. In: Wolanski E, McLusky D, Eds. Treatise on estuarine and coastal science, volume 5: biogeochemistry. Waltham: Academic Press. p 119-61.

Borges AV, Champenois W. 2015. Seasonal and spatial variability of dimethylsulfoniopropionate (DMSP) in the Mediterranean seagrass Posidonia oceanica. Aquat Bot 125:729 .

Borges AV, Darchambeau F, Teodoru CR, Marwick TR, Tamooh F, Geeraert N, Omengo FO, Guérin F, Lambert T, Morana C, Okuku E, Bouillon S. 2015. Globally significant greenhouse gas emissions from African inland waters. Nat Geosci 8:63742.

Borges AV, Champenois W, Gypens N, Delille B, Harlay J. 2016. Massive marine methane emissions from near-shore shallow coastal areas. Sci Rep 6:27908. doi:10.1038/srep27908.

Braeckman U, Yazdani Foshtomi M, Van Gansbeke D, Meysman F, Soetaert K, Vincx M, Vanaverbeke J. 2014. Variable importance of macrofaunal functional biodiversity for biogeochemical cycling in temperate coastal sediments. Ecosystems 17:720-37.

Crill PM, Martens CS. 1983. Spatial and temporal fluctuations of methane production in anoxic coastal marine sediments. Limnol Oceanogr 6:1117-30.

Damm E, Kiene RP, Schwarz J, Falck E, Dieckmann G. 2008. Methane cycling in Arctic shelf water and its relationship with phytoplankton biomass and DMSP. Mar Chem 109:45-59.

Damm E, Thoms S, Beszczynska-Möller A, Nöthig EM, Kattner G. 2015. Methane excess production in oxygen-rich polar water and a model of cellular conditions for this paradox. Polar Sci 9:327-34.

Damm E, Helmke E, Thoms S, Schauer U, Nöthig E, Bakker K, Kiene R. 2010. Methane production in aerobic oligotrophic surface water in the central Arctic Ocean. Biogeoscience 7:1099-108.

de Angelis MA, Lee C. 1994. Methane production during zooplankton grazing on marine phytoplankton. Limnol Oceanogr 39:1298-308.

de Haas H, van Weering TCE. 1997. Recent sediment accumulation, organic carbon burial and transport in the northeastern North Sea. Mar Geol 136:173-87.

Delhez EJM, Carabin G. 2001. Integrated modelling of the Belgian Coastal Zone. Estuar Coast Shelf Sci 53:477-91.

del Valle DA, Karl DM. 2014. Aerobic production of methane from dissolved water-column methylphosphonate and sinking particles in the North Pacific Subtropical Gyre. Aquat Microbial Ecol 73:93-105.

del Valle DA, Slezak D, Smith CM, Rellinger AN, Kieber DJ, Kiene RP. 2011. Effect of acidification on preservation of DMSP in seawater and phytoplankton cultures: Evidence for rapid loss and cleavage of DMSP in samples containing Phaeocystis sp. Mar Chem 124:57-67.

Díaz RJ, Rosenberg R. 2008. Spreading dead zones and consequences for marine ecosystems. Science 321:926-9.

Egger M, Lenstra W, Jong D, Meysman FJR, Sapart CJ, van der Veen C, Röckmann T, Gonzalez S, Slomp CP. 2016. Rapid sediment accumulation results in high methane effluxes from coastal sediments. Plos ONE. doi:10.1371/journal.pone. 0161609 . 
Faure K, Greinert J, Schneider von Deimling J, McGinnis DF, Kipfer R, Linke P. 2010. Methane seepage along the Hikurangi margin of New Zealand: Geochemical and physical data from the water column, sea surface and atmosphere. Mar Geol 272:170-88.

Florez-Leiva L, Damm E, Farías L. 2013. Methane production induced by dimethylsulfide in surface water of an upwelling ecosystem. Prog Oceanogr 112-113:38-48.

Gasparini S, Daro MH, Antajan E, Tackx M, Rousseau V, Parent JY, Lancelot C. 2000. Mesozooplankton grazing during the Phaeocystis globosa bloom in the Southern Bight of the North Sea. J Sea Res 4:345-56.

Gentz T, Damm E, Schneider von Deimling J, Mau S, McGinnis DF, Schlüter M. 2014. A water column study of methane around gas flares located at the West, Spitsbergen continental margin. Cont Shelf Res 72:107-18.

Graves CA, Steinle L, Rehder G, Niemann H, Connelly DP, Lowry D, Fisher RE, Stott AW, Sahling H, James RH. 2015. Fluxes and fate of dissolved methane released at the seafloor at the landward limit of the gas hydrate stability zone offshore western Svalbard. J Geophys Res 120:6185-201.

Grossart H-P, Frindte K, Dziallas C, Eckert W, Tang KW. 2011. Microbial methane production in oxygenated water column of an oligotrophic lake. Proc Nat Acad Sci USA 108:19657-61.

Gypens N, Borges AV, Speeckaert G, Lancelot C. 2014. The dimethylsulfide cycle in the eutrophied southern North Sea: a model study integrating phytoplankton and bacterial processes. PLoS ONE 9:e85862. doi:10.1371/journal.pone. 0085862.

Gypens N, Borges AV. 2014. Increase in dimethylsulfide (DMS) emissions due to eutrophication of coastal waters offsets their reduction due to ocean acidification. Front Mar Sci Mar Ecosyst Ecol 1:4. doi:10.3389/fmars.2014.00004.

Gypens N, Borges AV, Lancelot C. 2009. Effect of eutrophication on air-sea $\mathrm{CO}_{2}$ fluxes in the coastal Southern North Sea: a model study of the past 50 years. Global Change Biology 15:1040-56.

Holm-Hansen O, Lorenzen CJ, Holmes RW, Strickland JDH. 1965. Fluorometric determination of chlorophyll. J Cons Perm Int Explor Mer 30:3-15.

Høyer J, Karagali I. 2017. Sea surface temperature climate data record for the North Sea and Baltic Sea. J Clim. doi:10.1175/ JCLI-D-15-0663.1 (in press).

IPCC. 2013. Fifth assessment report of the intergovernmental panel on climate change. In: Stocker TF, Qin D, Plattner G-K, Tignor M, Allen SK, Boschung J, Nauels A, Xia Y, Bex V, Midgley PM Eds. Cambridge: Cambridge University Press. $p$ 1535.

Karl DM, Beversdorf L, Bjorkman KM, Church MJ, Martinez A, DeLong EF. 2008. Aerobic production of methane in the sea. Nat Geosci 1:473-8.

Karl DM, Tilbrook BD. 1994. Production and transport of methane in oceanic particulate organic matter. Nature 368:732-4.

Keller MD, Belows WK, Guillard RRL. 1989. Dimethyl sulfide production in marine phytoplankton. In: Saltzman E, Cooper WJ, Eds. Biogenic sulfur in the environment. Washington, DC: American Chemical Society. p 167-82.

Kiene RP. 1991. Production and consumption of methane in aquatic systems. In: Rogers JE, Whitman WB, Eds. Microbial production and consumption of greenhouse gases: methane, nitrogen oxides, and halomethanes. Washington DC: American Society for Microbiology. p 111-46.
Kirschke S, Bousquet P, Ciais P, Saunois M, Canadell JG, Dlugokencky EJ, Bergamaschi P, Bergmann D, Blake DR, Bruhwiler L, Cameron-Smith P, Castaldi S, Chevallier F, Feng L, Fraser A, Heimann M, Hodson EL, Houweling S, Josse B, Fraser PJ, Krummel PB, Lamarque J-F, Langenfelds RL, Le Quere C, Naik V, O'Doherty S, Palmer PI, Pison I, Plummer D, Poulter B, Prinn RG, Rigby M, Ringeval B, Santini M, Schmidt M, Shindell DT, Simpson IJ, Spahni R, Steele LP, Strode SA, Sudo K, Szopa S, van der Werf GR, Voulgarakis A, van Weele M, Weiss RF, Williams JE, Zeng G. 2013. Three decades of global methane sources and sinks. Nat Geosci 6:813-23.

Lancelot C, Spitz Y, Gypens N, Ruddick K, Becquevort S, Rousseau V, Lacroix G, Billen G. 2005. Modelling diatom and Phaeocystis blooms and nutrient cycles in the Southern Bight of the North Sea: the MIRO model. Mar Ecol Prog Ser 289:6378.

Lancelot C, Gypens N, Billen G, Garnier J, Roubeix V. 2007. Testing an integrated river-ocean mathematical tool for linking marine eutrophication to land use: the Phaeocystis-dominated Belgian coastal zone (Southern North Sea) over the past 50 years. J Mar Syst 64:216-28.

Le Bot S, Van Lancker V, Deleu S, De Batist M, Henriet JP, Haegeman W. 2005. Geological characteristics and geotechnical properties of Eocene and Quaternary deposits on the Belgian continental shelf: synthesis in the context of offshore wind farming. Neth J Geosci 84:147-60.

Lenhart K, Klintzsch T, Langer G, Nehrke G, Bunge M, Schnell S, Keppler F. 2016. Evidence for methane production by marine algae (Emiliana huxleyi) and its implication for the methane paradox in oxic waters. Biogeosciences 13:3163-74.

Martens CS, Albert DB, Alperin MJ. 1998. Biogeochemical processes controlling methane in gassy coastal sediments-Part 1. A model coupling organic matter flux to gas production, oxidation and transport. Cont Shelf Res 18:1741-70.

Mau S, Gentz T, Körber J-H, Torres ME, Römer M, Sahling H, Wintersteller P, Martinez R, Schlüter M, Helmke E. 2015. Seasonal methane accumulation and release from a gas emission site in the central North Sea. Biogeosciences 12:5261-76.

Mau S, Valentine DL, Clark JF, Reed J, Camilli R, Washburn L. 2007. Dissolved methane distributions and air-sea flux in the plume of a massive seep field, Coal Oil Point, California. Geophys Res Lett 34:L22603. doi:10.1029/2007GL031344.

Metcalf WW, Griffin BM, Cicchillo RM, Gao J, Janga SC, Cooke HA, Circello BT, Evans BS, Martens-Habbena W, Stahl DA, van der Donk WA. 2012. Synthesis of methylphosphonic acid by marine microbes: a source for methane in the aerobic ocean. Science 337:1104-7.

Middelburg JJ, Klaver G, Nieuwenhuize J, Wielemaker A, de Haas W, Vlug T, van der Nat JFWA. 1996. Organic matter mineralization in intertidal sediments along an estuarine gradient. Mar Ecol Prog Ser 132:157-68.

Middelburg JJ, Nieuwenhuize J, Iversen N, Høgh N, De Wilde H, Helder W, Seifert R, Christof O. 2002. Methane distribution in European tidal estuaries. Biogeochemistry 59:95-119.

Missiaen T, Murphy S, Loncke L, Henriet J-P. 2002. Very highresolution seismic mapping of shallow gas in the Belgian coastal zone. Cont Shelf Res 22:2291-301.

Mommaerts J-P, Pichot G, Ozer J, Adam YA, Baeyens WFJ. 1984. Nitrogen cycling and budget in Belgian coastal waters: North Sea areas with and without river inputs. Rapports et Procès-Verbaux du Conseil International pour l'Exploration de la Mer 183:57-69. 
Naqvi SWA, Bange HW, Farias L, Monteiro PMS, Scranton MI, Zhang J. 2010. Marine hypoxia/anoxia as a source of $\mathrm{CH}_{4}$ and $\mathrm{N}_{2} \mathrm{O}$. Biogeosciences 7:2159-90.

Nightingale PD, Malin G, Law CS, Watson AJ, Liss PS, Liddicoat MI, Boutin J, Upstill-Goddard RC. 2000. In situ evaluation of air-sea gas exchange parameterizations using novel conservative and volatile tracers. Global Biogeochem Cycles 14:37387.

Oremland RS. 1975. Methane production in shallow-water, tropical marine sediments. Appl Microbiol 30:602-8.

Oremland RS. 1979. Methanogenic activity in plankton samples and fish intestines: a mechanism for in situ methanogenesis in oceanic surface waters. Limnol Oceanogr 24:1136-41.

Provoost P, Braeckman U, Van Gansbeke D, Moodley L, Soetaert K, Middelburg JJ, Vanaverbeke J. 2013. Modelling benthic oxygen consumption and benthic-pelagic coupling at a shallow station in the southern North Sea. Estuar Coast Shelf Sci 120:1-11.

Rauch M, Denis L, Dauvin J-C. 2008. The effects of Phaeocystis globosa bloom on the dynamics of the mineralization processes in intertidal permeable sediment in the Eastern English Channel (Wimereux, France). Mar Pollut Bull 56:1284-93.

Rehder G, Keir RS, Suess E, Pohlmann T. 1998. The multiple sources and patterns of methane in North Sea waters. Aquat Geochem 4:403-27.

Repeta DJ, Ferrón S, Sosa OA, Johnson CG, Repeta LD, Acker M, DeLong EF, Karl DM. 2016. Marine methane paradox explained by bacterial degradation of dissolved organic matter. Nat Geosci. doi:10.1038/NGEO2837.

Rhee TS, Kettle AJ, Andreae MO. 2009. Methane and nitrous oxide emissions from the ocean: a reassessment using basinwide observations in the Atlantic. J Geophys Res 114:D12304. doi:10.1029/2008JD011662.

Rousseau V, Leynaert A, Daoud N, Lancelot C. 2002. Diatom succession, silicification and silicic acid availability in Belgian coastal waters (Southern North Sea). Mar Ecol Prog Ser 236:61-73.

Saunois M, Bousquet P, Poulter B, Peregon A, Ciais P, Canadell JG, Dlugokencky EJ, Etiope G, Bastviken D, Houweling S, Janssens-Maenhout G, Tubiello FN, Castaldi S, Jackson RB, Alexe M, Arora VK, Beerling DJ, Bergamaschi P, Blake DR, Brailsford G, Brovkin V, Bruhwiler L, Crevoisier C, Crill P, Kovey K, Curry C, Frankenberg C, Gedney N, HöglundIsaksson L, Ishizawa M, Ito A, Joos F, Kim H-S, Kleinen T, Krummel P, Lamarque J-F, Langenfelds R, Locatelli R, Machida T, Maksyutov S, McDonald KC, Marshall J, Melton JR, Morino I, Naik V, O'Doherty S, Parmentier F-JW, Patra PK, Peng C, Peng S, Peters G, Pison I, Prigent C, Prinn R, Ramonet M, Riley WJ, Saito M, Sanyini M, Schroeder R, Simpson IJ, Spahni R, Steele P, Takizawa A, Thornton BF, Tian H, Tohjima Y, Viovy N, Voulgarakis A, van Weele $M$, van der Werf G, Weiss R, Wiedinmyer C, Wilton DJ, Wiltshire A, Worthy D, Wunch DB, Xu X, Yoshida Y, Zhang B, Zhang Z, Zhu Q. 2016. The global methane budget. Earth Syst Sci Data 8:697-751.

Sawicka JE, Brüchert V. 2017. Annual variability and regulation of methane and sulfate fluxes in Baltic Sea estuarine sediments. Biogeosciences 14:325-39.

Schmale O, Beaubien SE, Rehder G, Greinert J, Lombardi S. 2010. Gas seepage in the Dnepr paleo-delta area (NW-Black Sea) and its regional impact on the water column methane cycle. J Mar Syst 80:90-100.

Schneider von Deimling J, Rehder G, Greinert J, McGinnnis DF, Boetius A, Linke P. 2011. Quantification of seep-related me- thane gas emissions at Tommeliten, North Sea. Cont Shelf Res 31:867-78.

Schulz S, Matsuyama H, Conrad R. 1997. Temperature dependence of methane production from different precursors in a profundal sediment (Lake Constance). FEMS Microbiol Ecol 22:207-13.

Scranton MI, McShane K. 1991. Methane fluxes in the southern North Sea: the role of European rivers. Cont Shelf Res 11:3752.

Shakhova N, Semiletov I, Leifer I, Salyuk A, Rekant P, Kosmach D. 2010. Geochemical and geophysical evidence of methane release over the East Siberian Arctic Shelf. J Geophys Res 115:C08007. doi:10.1029/2009JC005602.

Simó R, Vila-Costa M. 2006. Ubiquity of algal dimethylsulfoxide in the surface ocean: geographic and temporal distribution patterns. Mar Chem 100:136-46.

Smith SR, Legler DM, Verzone KV. 2001. Quantifying uncertainties in NCEP reanalyses using high-quality research vessel observations. J Clim 14:4062-72.

Solomon EA, Kastner M, MacDonald IR, Leifer I. 2009. Considerable methane fluxes to the atmosphere from hydrocarbon seeps in the Gulf of Mexico. Nat Geosci 2:561-5.

Stanley E, Casson NJ, Christel ST, Crawford JT, Loken LC, Oliver SK. 2015. The ecology of methane in streams and rivers: patterns, controls, and global significance. Ecol Monogr $86: 146-71$

Stefels J. 2009. Determination of DMS DMSP, and DMSO in seawater. In: Wurl O, Ed. Practical guidelines for the analysis of seawater. Boca Raton, Florida: CRC Press Taylor \& Francis Group. p 223-34.

Stefels J, Steinke M, Turner SM, Malin G, Belviso S. 2007. Environmental constraints on the production and removal of the climatically active gas dimethylsulphide (DMS) and implications for ecosystem modelling. Biogeochemistry 83:245-75.

Turner SM, Malin G, Liss PS, Harbour DS, Holligan PM. 1988. The seasonal variation of dimethyl sulphide and DMSP concentrations in nearshore waters. Limnol Oceanogr 33:364-75.

Turner SM, Malin G, Nightingale PD, Liss PS. 1996. Seasonal variation of dimethyl sulphide in the North Sea and an assessment of fluxes to the atmosphere. Mar Chem 54:24562.

Upstill-Goddard RC, Barnes J, Frost T, Punshon S, Owens NJP. 2000. Methane in the southern North Sea: low-salinity inputs, estuarine removal, and atmospheric flux. Global Biogeochem Cycles 14:1205-17.

Upstill-Goddard RC, Barnes J. 2016. Methane emissions from UK estuaries: re-evaluating the estuarine source of tropospheric methane from Europe. Mar Chem 180:14-23.

van der Zee C, Chou L. 2005. Seasonal cycling of phosphorus in the Southern Bight of the North Sea. Biogeosciences 2:27-42.

Verfaillie E, Van Lancker V, Van Meirvenne M. 2006. Multivariate geostatistics for the predictive modelling of the surficial sand distribution in shelf seas. Cont Shelf Res 26:2454-68.

Wanninkhof R. 1992. Relationship between wind speed and gas exchange over the ocean. J Geophys Res 97:7373-82.

Ward BB, Kilpatrick KA. 1990. Relationship between substrate concentration and oxidation of ammonium and methane in a stratified water column. Cont Shelf Res 10:1193-208.

Wever TF, Abegg F, Fiedler HM, Fechner G, Stender IH. 1998. Shallow gas in the muddy sediments of Eckernförde Bay, Germany. Cont Shelf Res 18:1715-39. 
Yvon-Durocher G, Allen AP, Bastviken D, Conrad R, Gudasz C, St-Pierre A, Thanh-Duc N, del Giorgio PA. 2014. Methane fluxes show consistent temperature dependence across microbial to ecosystem scales. Nature 507:488-91.

Zindler C, Bracher A, Marandino CA, Taylor B, Torrecilla E, Kock A, Bange HW. 2013. Sulphur compounds, methane, and phytoplankton: interactions along a north-south transit in the western Pacific Ocean. Biogeosciences 10:3297-311.

Zeikus JG, Winfrey MR. 1976. Temperature limitation of methanogenesis in aquatic sediments. Appl Environ Microbiol 31:99-107. 